\title{
Iron Fertilization with Enhanced Phytoplankton Productivity under Minimal Sulfur Compounds and Grazing Control Analysis in HNLC Region
}

\author{
Tai-Jin Kim ${ }^{1 *}$, G. H. Hong², D. G. Kim³ ${ }^{3}$ Mark Baskaran ${ }^{4}$ \\ ${ }^{1}$ Department of Chemical Engineering, The University of Suwon, Hwasung-City, Republic of Korea \\ ${ }^{2}$ Korea Institute of Ocean Science Technology, Ansan-City, Republic of Korea \\ ${ }^{3}$ LED Agri-Bio Fusion Technology Research Center, Chonbuk National University, Icksan-City, Republic of Korea \\ ${ }^{4}$ Department of Geology, Wayne State University, Detroit, MI, USA \\ Email: tjkim@suwon.ac.kr
}

How to cite this paper: Kim, T.-J., Hong, G.H., Kim, D.G. and Baskaran, M. (2019) Iron Fertilization with Enhanced Phytoplankton Productivity under Minimal Sulfur Compounds and Grazing Control Analysis in HNLC Region. American Journal of Climate Change, 8, 14-39. https://doi.org/10.4236/ajcc.2019.81002

Received: November 7, 2018

Accepted: January 22, 2019

Published: January 25, 2019

Copyright () 2019 by author(s) and Scientific Research Publishing Inc. This work is licensed under the Creative Commons Attribution International License (CC BY 4.0).

http://creativecommons.org/licenses/by/4.0/

\section{(c) (i) Open Access}

\begin{abstract}
The present study investigated quantitatively the significance of HNLC (high-nutrient low-chlorophyll) regions and its grazing control with the improved iron fertilization for climate change. The limitation of iron $(\mathrm{Fe})$ for phytoplankton growth in HNLC regions was confirmed by sulfur compounds (S) such as volcanic ash and hydrogen sulfide $\left(\mathrm{H}_{2} \mathrm{~S}\right)$ in batch cultures, whose chemical sediment of $\mathrm{Fe}_{3} \mathrm{~S}_{4}$ showed $4.06 \mathrm{wt} \%$. The technologies developed for iron fertilization since 1993 till now were not practical to provide sufficient amounts of bioavailable iron due to sedimentary iron sulfides induced by undersea volcanic sulfur compounds. The proposed technology for iron fertilization was improved to enhance the bioavailable iron to phytoplankton by keeping minimal sulfur compounds in HNLC regions. The low productivity of phytoplankton by grazing control in HNLC regions was 6\% diatoms whose $52 \%$ was grazed by copepods and $42 \%$ by krill on the basis of data analysis in 2000 EisenEx Experiment at boundary of Antarctic and African tectonic plates. All of the previous iron fertilization experiments were conducted at volcanic sulfur compounds enriched HNLC regions. The present study revealed that the enhanced phytoplankton productivity in batch culture without sedimentary iron sulfides can be possible only if sulfur compounds are minimal, as is in Shag Rocks $\left(53^{\circ} \mathrm{S}, 42^{\circ} \mathrm{W}\right)$ of South Georgia in Scotia Sea in the Southern Ocean.
\end{abstract}

\section{Keywords}

Iron Fertilization, Phytoplankton, Productivity, Grazing Control Analysis, Minimal Sulfur Compounds 


\section{Introduction}

The hypothesis of iron fertilization was speculated by English biologist Joseph Hart in 1934, raised by John Gribbin in 1988, and renewed by American oceanographer John Martin four months later. As reviewed by Dugdale and Wilkerson [1], Barber and Ryther described an area of east of the Galapagos Islands in 1969 and Strickland et al. had interests in waters exhibiting relatively abundant nutrients, but low chlorophyll and low productivity in 1969. Minas et al. had firstly designated the terms of "high nutrient, low chlorophyll (HNLC)" in 1986. Martin's iron enrichment experiments into the amounts of carbon drawn into the seas by algae formed the basis for 14 mesoscale efforts during the last 24 years. Martin and Fitzwater [2] hypothesized in 1988 that primary productivity in HNLC regions was limited by the availability of iron (Fe). Hematite $\left(\mathrm{Fe}_{2} \mathrm{O}_{3}\right)$ and goethite $(\mathrm{FeO}(\mathrm{OH}))$ in the aeolian dust tend to be associated with fine $(0.3$ $1 \mu \mathrm{m}$ ) particles, with long residence times (days) in the atmosphere and thus potentially long transport paths [3]. If Fe reacts with dissolved sulfur (S) under steam heating $\left(\mathrm{T}>600^{\circ} \mathrm{C}\right)$ conditions [4], the product results in insoluble black ferrous sulfide $(\mathrm{FeS})$, which reacts again with acidic hydrogen sulfide $\left(\mathrm{H}_{2} \mathrm{~S}\right)$ to form pyrite $\left(\mathrm{FeS}_{2}\right)$ and hydrogen $\left(\mathrm{H}_{2}\right)$ [5]. The existence of HNLC regions was attributed to constant zooplankton grazing over phytoplankton, trace metal toxicity, limitation of iron input, light limitation due to the deep mixed layer. However, none of these factors have been proved conclusively [1] [6]. Woods Hole Oceanographic Institution studied the design for a mesoscale iron enrichment experiment with several questions such as where should the experiment be performed and what would be used as an iron source [7]. No one has yet clearly answered to these questions even if 14 iron enrichment experiments were conducted in HNLC regions. The goal of the present study was to examine empirically the Fe limitations induced by $\mathrm{S}$ compounds of volcanic ash and hydrogen sulfide to improve the iron fertilization for the maximal phytoplankton productivity and estimate analytically the grazing control by copepods and krill over diatoms in HNLC regions.

\section{Results and Discussion}

\subsection{Mass Balance of Iron in Global Surface Ocean}

In order to differentiate the global ocean into four oceanic regions in terms of accumulation rates of iron $(\mathrm{Fe})$ and sulfur $(\mathrm{S})$, the accumulation rate of $\mathrm{Fe}$ in the ocean, $\left(\frac{\mathrm{d} F e}{\mathrm{~d} t}\right)$, is given by :

$$
\frac{\mathrm{d} F e}{\mathrm{~d} t}=(\dot{F} e)_{i n}-(\dot{F} e)_{o u t}+(\dot{F} e)_{g e n}-(\dot{F} e)_{c o n}-(\dot{F} e)_{r x n}
$$

where:

$(\dot{F} e)_{i n}=$ the input rate of $\mathrm{Fe}\left(\mathrm{nmol} \cdot \mathrm{m}^{-2} \cdot \mathrm{d}^{-1}\right)$ from desert dust, volcanic ash, rivers, and bottom sediments, 
$(\dot{F e})_{\text {out }}=$ the output rate of Fe during Fe Cycle is negligible due to short term (hours) biological iron uptake,

$(\dot{F} e)_{\text {gen }}=$ the generation rate of Fe from vertical mixing, upwelling and biogenic recycling of cellular iron within the ocean [8],

$(\dot{F} e)_{c o n}=$ the consumption rate of Fe by phytoplankton assimilation,

$(\dot{F} e)_{r x n}=$ the removal term for dissolved Fe by scavenging on the sinking particulate matter and chemical reaction rate of Fe with volcanic $\mathrm{S}$ compounds as sedimentary $\mathrm{FeS}$ and $\mathrm{FeS}_{2}$.

Oceans are subdivided into four regions based on the amounts of nutrient and chlorophyll; HNLC (high-nutrient, low-chlorophyll), HNHC (high-nutrient, high-chlorophyll), LNLC (low-nutrient, low-chlorophyll), and LNHC (low-nutrient, high-chlorophyll), as shown in Table 1.

It is assumed that $\frac{\mathrm{d} F e}{\mathrm{~d} t} \gg 0$ for $\mathrm{HC}$ (high-chlorophyll) regions (as is in HNHC and LNHC) if Fe supplied largely from deserts and upwelling. When $\frac{\mathrm{d} F e}{\mathrm{~d} t}<0$ and the accumulation rate of volcanic S compounds, $\frac{\mathrm{d} S}{\mathrm{~d} t} \gg 0$ for LC (low-chlorophyll) regions (as is in HNLC and LNLC) are satisfied if Fe is rarely replenished from deserts and subsurface water upwelling while volcanic $S$ compounds are abundant. We present a review of the four oceanic regions listed above is presented here. 1) The southern Omani coast was studied to evaluate HNLC characteristics during the late Southwest Monsoon (Aug.-Sep.) [9]. Fe-replete dusts from the Arabian and Syrian deserts were blocked by high Omani mountains $(\sim 3000 \mathrm{~m})$ during the late Southwest Monsoon so that desert dusts could not reach the southern Omani coast, where many volcanoes are active (e.g. 13 volcanoes in Yemen), Saudi Arabia (24 volcanoes), Iran (7 volcanoes), Iraq (1 volcano), India (4 volcanoes), and Pakistan ( 7 volcanoes). Oxygen minimum zones in the Arabian Sea (not in the open ocean where HNLC water present) forms due to the oxidation of volcanic sulfur compounds of $\mathrm{S}, \mathrm{SO}_{2}, \mathrm{SO}_{3}$, and $\mathrm{H}_{2} \mathrm{SO}_{4}$ to sulfates $\left(\mathrm{SO}_{4}^{2-}\right.$ ) by consuming the dissolved oxygen in waters. Therefore, the contribution of volcanic $S$ compounds to the southern Omani coast during the late Southwest Monsoon is much greater than those of Fe from deserts to satisfy the condition $\frac{\mathrm{d} F e}{\mathrm{~d} t}<0, \frac{\mathrm{d} S}{\mathrm{~d} t} \gg 0$, and $\left|\frac{\mathrm{d} F e}{\mathrm{~d} t}\right| \ll\left|\frac{\mathrm{d} S}{\mathrm{~d} t}\right|$ for HNLC region. 2) Fertilization potential near the Anatahan volcano in the Northern Mariana Islands of western North Pacific Subtropical Gyre showed low concentrations of nitrate $(0.042 \mu \mathrm{M})$, phosphate $(0.003 \mu \mathrm{M})$, and iron $(0.002$ $\mu \mathrm{M})$, following the Anatahan eruption leading to the presence of the most oligotrophic LNLC ocean deserts on Earth [10] with chlorophyll-a of $0.07 \mu \mathrm{g} \cdot \mathrm{l}^{-1}$ [11]. In the western North Pacific Subtropical Gyre there are minimal Asian dust inputs and annually persistent Anatahan volcanic eruptions (2003, 2004, 2005, 2006, 2007, 2008) to satisfy the criteria of $\frac{\mathrm{d} F e}{\mathrm{~d} t}<0, \frac{\mathrm{d} S}{\mathrm{~d} t}>0$, and $\left|\frac{\mathrm{d} F e}{\mathrm{~d} t}\right|<\left|\frac{\mathrm{d} S}{\mathrm{~d} t}\right|$ for LNLC region. 3) Benguela upwelling system in Southwestern Africa is one of 
Table 1. Oceanic regions with relative accumulation rates of iron (Fe) from desert and sulfur (S) from volcano.

\begin{tabular}{|c|c|c|c|}
\hline \multirow{2}{*}{ Region } & \multirow{2}{*}{$\begin{array}{c}\text { Oceanic Location } \\
\text { (Relative Accumulation } \\
\text { Rates of } \mathrm{Fe} \text { and } \mathrm{S} \text { ) }\end{array}$} & \multicolumn{2}{|c|}{ Major Nutrient Sources } \\
\hline & & Desert $(\mathrm{Fe})$ & Volcano (Number) (S) \\
\hline HNLC & $\begin{array}{l}\text { 1) Southern Ocean } \\
\text { 2) Equatorial Pacific } \\
\text { 3) Subarctic Pacific } \\
\text { ( } \frac{\mathrm{d} F e}{\mathrm{~d} t}<0, \frac{\mathrm{d} S}{\mathrm{~d} t} \gg 0 \text { ) } \\
\left.\text { ( }\left|\frac{\mathrm{d} F e}{\mathrm{~d} t}\right| \ll\left|\frac{\mathrm{d} S}{\mathrm{~d} t}\right|\right)\end{array}$ & $\begin{array}{l}\text { 1) Austalian/Patagonian/ } \\
\text { Kalahari/Antarctic Polar } \\
\text { 2) Gobi/Atacama } \\
\text { 3) Gobi }\end{array}$ & $\begin{array}{l}\text { 1) Erebus (Antarctica) (19)/ } \\
\text { Huaynaputina (Peru) (29)/ } \\
\text { Hudson (Chile) (137) } \\
\text { 2) Huaynaputina (Peru) (29)/ } \\
\text { Hudson (Chile) (137)/ } \\
\text { Cotopaxi (Ecuador)(43) } \\
\text { Galapagos Islands } \\
\text { (Ecuador) (12) } \\
\text { 3) Aleutian (40)/ } \\
\text { Augustine (USA) (15)/ } \\
\text { Kamchatka (Russia)(29) }\end{array}$ \\
\hline LNLC & $\begin{array}{l}\text { 1) Ryu Kyu/Izu-Bonin Arc } \\
\text { 2) Hawaii } \\
\text { 3) western North Pacific } \\
\text { Subtropical Gyre/Guam } \\
\text { 4) Iceland } \\
\left(\frac{\mathrm{d} F e}{\mathrm{~d} t}<0, \frac{\mathrm{d} S}{\mathrm{~d} t}>0\right) \\
\left(\left|\frac{\mathrm{d} F e}{\mathrm{~d} t}\right|<\left|\frac{\mathrm{d} S}{\mathrm{~d} t}\right| \text { ) }\right.\end{array}$ & $\begin{array}{l}\text { 1) Gobi } \\
\text { 2) (Gobi) } \\
\text { 3) (Gobi) } \\
\text { 4) Highlands of } \\
\text { volcanic desert }\end{array}$ & $\begin{array}{l}\text { 1) Japan (108) } \\
\text { 2) Hawaii (15) } \\
\text { 3) Anatahan (USA) } \\
\text { 4) Iceland (130) }\end{array}$ \\
\hline HNHC & $\begin{array}{l}\text { Benguela upwelling system } \\
\left(\frac{\mathrm{d} F e}{\mathrm{~d} t} \gg 0, \frac{\mathrm{d} S}{\mathrm{~d} t}<0\right) \\
\left(\left|\frac{\mathrm{d} F e}{\mathrm{~d} t}\right| \gg\left|\frac{\mathrm{d} S}{\mathrm{~d} t}\right|\right)\end{array}$ & Kalahari, Namib & $\begin{array}{l}\text { None active but extinct; } \\
\text { Angola(0), Namibia (1), } \\
\text { South Africa (4) }\end{array}$ \\
\hline LNHC & $\begin{array}{l}\text { 1) Pacific coast of Mexico } \\
\text { 2) Northeast Pacific } \\
\text { 3) Northwest Pacific } \\
\text { 4) Northeastern Canada } \\
\text { 5) Peruvian coast } \\
\text { 6) New Zealand } \\
\text { 7) Southern Africa } \\
\text { 8) The Antarctic } \\
\left(\frac{\mathrm{d} F e}{\mathrm{~d} t} \gg 0, \frac{\mathrm{d} S}{\mathrm{~d} t}>0 \text { ) }\right. \\
\text { ( }\left|\frac{\mathrm{d} F e}{\mathrm{~d} t}\right|>\left|\frac{\mathrm{d} S}{\mathrm{~d} t}\right| \text { ) }\end{array}$ & $\begin{array}{l}\text { 1) Chihuahuan, } \\
\text { Sonoran, Mojave } \\
\text { 2) Gobi, Great Basin } \\
\text { 3) Gobi } \\
\text { 4) Arctic, Sahara } \\
\text { 5) Patagonian, Atacama } \\
\text { 6) Great Victoria, Great } \\
\text { Sandy, } \\
\text { Gibson, Simpson } \\
\text { 7) Kalahari, Namib } \\
\text { 8) Antarctic, Great } \\
\text { Victoria, Great } \\
\text { Sandy, Gibson, Simpson, } \\
\text { Patagonian, Atacama, } \\
\text { Kalahari, } \\
\text { Namib }\end{array}$ & $\begin{array}{l}\text { 1) Barcena, Socorro and } \\
9 \text { others } \\
\text { 2) Augustine (15), } \\
\text { Kasatochi, Redoubt (13) } \\
\text { Pavlof (40), Cleveland (19) } \\
\text { 3) Hokkaido (17), Honshu } \\
\text { (46), } \\
\text { 4) Greenland, Iceland, New- } \\
\text { foundland } \\
\text { Seamounts, Fogo Seamounts } \\
\text { 5) Peru (29) and Chile (137) } \\
\text { 6) White Island, Kermadec } \\
\text { Islands } \\
\text { 7) Madagascar (5), Mozambi- } \\
\text { que (1), } \\
\text { Tanzania (22), South Africa } \\
\text { (4) } \\
\text { 8) Erebus (19) }\end{array}$ \\
\hline
\end{tabular}

the most productive fishery areas in the world with sand storms from Kalahari and Namib deserts in winter without any active volcanoes (Table 1).

There are four more regions associated with major fisheries and coastal upwelling Currents-; 1) Canary Current with Sahara desert but no volcanoes; 2) 
California Current with deserts of Mojave, Colorado and Great Basin but no active volcanoes; 3) Humboldt Current with desert of Atacama but no volcanic fallout due to Chilean volcanic ashes blown to the south and Argentina; and 4) Somali Current with desert of Danakil-Kaisut but no fallout of volcanic ashes since Southwest Monsoon during summer moves three active volcanic ashes from northeastward along with the coastal waters. These five coastal upwelling regions meet the criteria of $\frac{\mathrm{d} F e}{\mathrm{~d} t} \gg 0, \frac{\mathrm{d} S}{\mathrm{~d} t}<0$, and $\left|\frac{\mathrm{d} F e}{\mathrm{~d} t}\right| \gg\left|\frac{\mathrm{d} S}{\mathrm{~d} t}\right|$ for HNHC regions. 4) Indonesia has 127 active volcanoes but no desert. However, western Australian dusts from Great Victoria, Great Sandy, Gibson, Tanami, and Little Sandy deliver Fe-enriched dusts (7 - 18 wt\% Fe compared to the common 3.5 $6.0 \mathrm{wt} \%)$ to Indonesian marine waters. Java Sea is surrounded by active volcanoes while the South Java Current flows eastward along the coast during the Northwest Monsoons. Nitrate $(0.5-1.5 \mu \mathrm{M})$, phosphate $(0.05-0.4 \mu \mathrm{M})$, silicate $(4-14 \mu \mathrm{M})$, and chlorophyll-a $\left(0.3-1.0 \mu \mathrm{g} \cdot \mathrm{l}^{-1}\right)$ were monitored in Java Sea [12], where is a major fishing ground in Indonesia. Java Sea of Indonesia meets the criteria: $\frac{\mathrm{d} F e}{\mathrm{~d} t} \gg 0, \frac{\mathrm{d} S}{\mathrm{~d} t}>0$, and $\left|\frac{\mathrm{d} F e}{\mathrm{~d} t}\right|>\left|\frac{\mathrm{d} S}{\mathrm{~d} t}\right|$ for LNHC region. Therefore, the present scheme of categorizing oceans in HNLC, LNLC, HNHC and LNHC regions by using the relative magnitude of the accumulation rates of Fe from deserts and subsurface water upwelling while $S$ from volcanic sulfur compound, as illustrated in Table 1, appears to be reasonable.

\subsection{Estimation of Desulfurization Time from Fresh Volcanic Ashes}

Iron in volcanic ashes have been reported in a number of complex forms that include $\mathrm{Fe}_{2} \mathrm{O}_{3}, \mathrm{Fe}_{3} \mathrm{O}_{4}, \mathrm{FeCl}_{2}, \mathrm{FeCl}_{3}, \mathrm{FeF}_{2}, \mathrm{FeF}_{3}, \mathrm{FeS}, \mathrm{FeS}_{2}, \mathrm{FeSO}_{4}$ and $\mathrm{Fe}_{2}\left(\mathrm{SO}_{4}\right)_{3}$ [13]. Fresh volcanic ash from Japanese Ontake volcano erupted in September $27^{\text {th }}$, 2014, was sampled a week later after its eruption to determine concentration of sulfur (Table 2).

Volcanic ash samples from 5 other volcanic eruptions, as morphologically examined in Figure 1, Mount Baekdu of Korea, Mount St. Helens of Washington, Mount Pinatubo of Philippines, Lombok of Indonesia, and Kasatochi of Alaska, were also collected for S concentration. Since the Fe/S ratios of all the aged volcanic ash samples (Table 2) were far greater (10.8 - 191.8) than that of the fresh Ontake volcanic ash (1.13), it was evident that volcanic sulfur was diminished likely due to weathering, as shown in Figure 2.

The relationship between $S$ content and the elapsed time was modeled by the first order decay [14] as $\left(\ln \frac{C_{A}}{C_{A O}}=-k t\right)$, and the resulted rate constant $(k)$ of $0.1392 \mathrm{y} \cdot \mathrm{r}^{-1}$ from the slope of Figure 2 . This rate constant was used to estimate a time necessary for fresh volcanic ash to release $S$ in the surface of the earth, using the equation of $\left\{t=\frac{\ln \left(\frac{1}{29531}\right)}{-0.1392 \mathrm{yr}^{-1}}\right\}$, by assuming all four volcanic ash from 


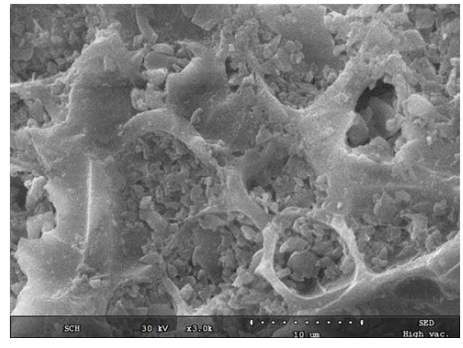

(a)

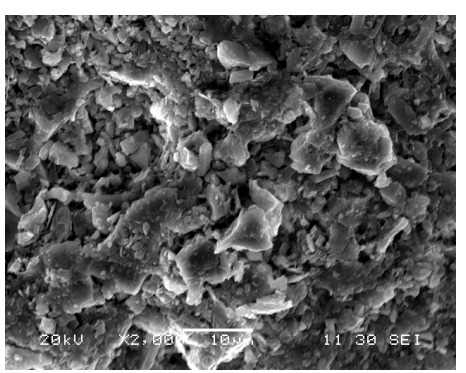

(b)

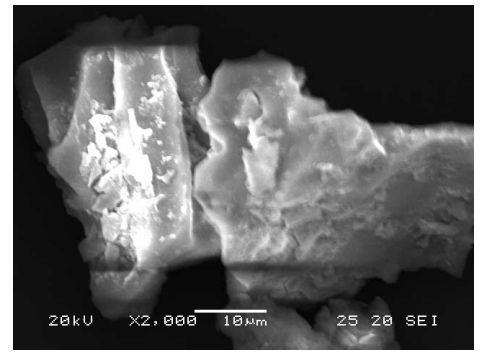

(c)

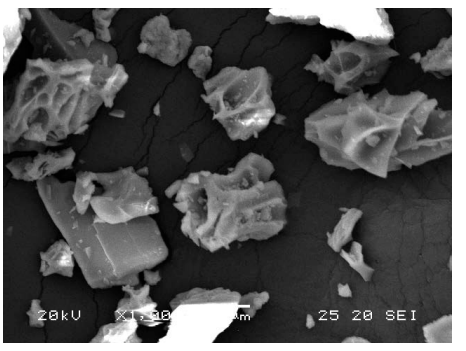

(d)

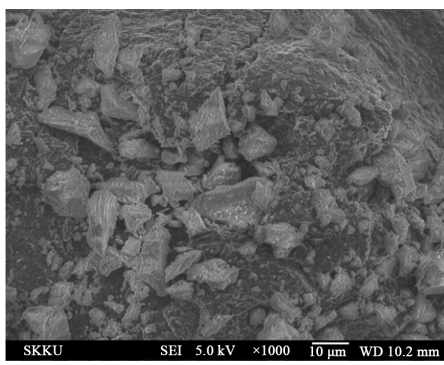

(e)

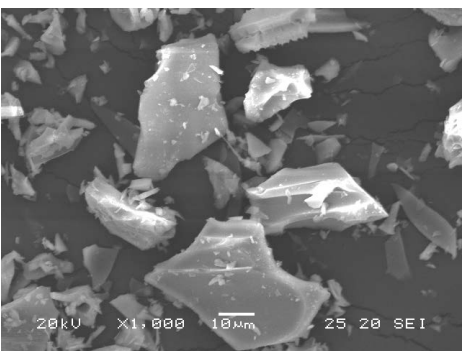

(f)

Figure 1. Morphology of volcanic samples by scanning electron microscopy (SEM). The numbers indicated the year of volcanic eruption with the magnification folds $(x)$. (a) Japanese Ontake (erupted in 2004) (×3000); (b) Alaska Kasatochi $(2008)(\times 2000)$; (c) Indonesian Lombok (1994) (×2000); (d) Philippines Pinatubo (1991) $(\times 1000)$; (e) Washington St. Helens (1980) (×1000); (f) Korean Baekdu (969) $(\times 1000)$.

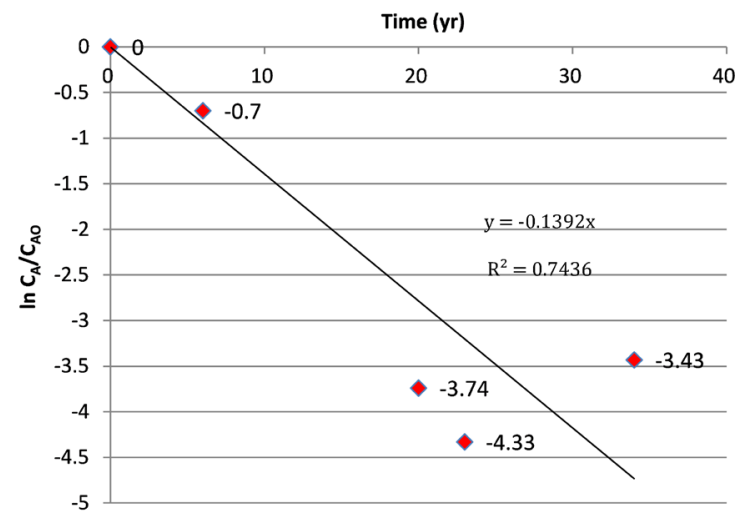

Figure 2. The first order decay of volcanic sulfur to estimate the elapsed time of 74 years $\left\{t=\frac{\ln \left(\frac{1}{29531}\right)}{-0.1392 \mathrm{yr}^{-1}}\right\}$, for desulfurization of the volcanogenic sulfur available from various volcanic ashes (data from Table 2) since the volcanic eruption. 
Table 2. Characteristics of volcanic ashes, volcanic stone, and soil around the world.

\begin{tabular}{|c|c|c|c|c|c|c|c|}
\hline Volcano & $\begin{array}{l}\text { Eruption } \\
\text { (year) }\end{array}$ & $\begin{array}{c}\mathrm{Fe} \\
(\mathrm{mg} / \mathrm{kg})\end{array}$ & $\begin{array}{c}\mathrm{C}_{\mathrm{A}} \\
\mathrm{S}(\mathrm{mg} / \mathrm{kg})\end{array}$ & $\mathrm{Fe} / \mathrm{S}$ & $\mathrm{C}_{\mathrm{A}} / \mathrm{C}_{\mathrm{AO}} \mathrm{b}^{\mathrm{b}}$ & $\ln C_{A} / C_{A O}$ & $\begin{array}{c}\operatorname{Time}^{\mathrm{c}} \\
(\mathrm{yr})\end{array}$ \\
\hline Mount Ontake, Japan & 2014 & 33,312 & 29,531 & 1.13 & 1 & 0 & 0 \\
\hline Kasatochi, Alaska & 2008 & 157,942 & 14,572 & 10.8 & 0.493 & -0.70 & 6 \\
\hline Lombok, Indonesia & 1994 & 60,961 & 701 & 87.0 & 0.0240 & -3.74 & 20 \\
\hline $\begin{array}{l}\text { Mount Pinatubo, } \\
\text { Philippines }\end{array}$ & 1991 & 73,857 & 385 & 191.8 & 0.0130 & -4.33 & 23 \\
\hline $\begin{array}{l}\text { Mount St. Helens, } \\
\text { Washington }\end{array}$ & 1980 & 23,235 & 955 & 24.3 & 0.0323 & -3.43 & 34 \\
\hline \multicolumn{8}{|l|}{ Volcanic stone } \\
\hline Mount Baekdu ${ }^{a}$ & 969 & 24,368 & 191 & 127.6 & - & - & - \\
\hline \multicolumn{8}{|l|}{ Soil } \\
\hline Tongyoung, Korea & - & 26,014 & 1350 & 19.3 & - & - & - \\
\hline
\end{tabular}

Note: ${ }^{\mathrm{a} V o l c a n i c}$ stone not ash; ${ }^{\mathrm{b}} \mathrm{C}_{\mathrm{AO}}$ was taken from Ontake; and ${ }^{\mathrm{c} T i m e}$ elapsed since 2014 of Ontake eruption. Concentrations of sulfur and iron were measured using an inductively coupled plasma (ICP) (Optima 5300DV, Perkin Elmer).

Mount St. Helens, Mount Pinatubo, Lombok, and Kasatochi, had the same initial sulfur concentration of the fresh Ontake volcanic ash. Based on the present data set in Figure 2, 74 years was required to release $S$ from the fresh volcanic ash left on the oxygenated surface of the earth.

\subsection{Phytoplankton Productivity with Iron (Fe) and Volcanic Ash}

The effects of Fe and volcanic ash upon the growth of phytoplankton were experimentally examined under aerobic culture of Chlorella vulgaris with various JM media; with its own $\mathrm{Fe}$, mixture of $75 \%$ clay and $25 \%$ volcanic ash, fresh $100 \%$ volcanic ash, without its own Fe. The growth curves for 4 similarity experiments of 4 ecosystems (Table 1) of HNHC (high nutrient, high chlorophyll), HNLC (high nutrient, low chlorophyll), LNHC (low nutrient, high chlorophyll), LNLC (low nutrient, high chlorophyll) were shown in Figure 3 after three reproducible measurements in six days batch cultures expressed by negligible error bar for the standard deviation at each point. $150 \mathrm{ml} \mathrm{JM}$ medium without Fe was used as the base medium for the case of HNLC while $0.1 \mathrm{~g}$ of Japanese Ontake volcanic ash (100\% volcanic ash) was added to JM medium without Fe for the case of LNLC. A mixture of $0.075 \mathrm{~g}$ of Tongyoung clay and $0.025 \mathrm{~g}$ of Ontake volcanic ash, was added to $150 \mathrm{ml} \mathrm{JM}$ medium without Fe for the case of LNHC while JM medium with its own Fe was used for the case of HNHC. The 100\% volcanic ash (V100) showed the low growth of phytoplankton, similar to LNLC regions. The base medium without $\mathrm{Fe}$ showed the lowest growth, similar to HNLC regions. The present similarity experiments were in good agreement with the phytoplankton productivity of oceanic regions in the sequence of HNHC > LNHC > LNLC > HNLC in Table 1. The present results of bottle experiments showed similar growth patterns of "with iron" (+Fe) and "without iron" $(-\mathrm{Fe})$ in Martin [6]. 


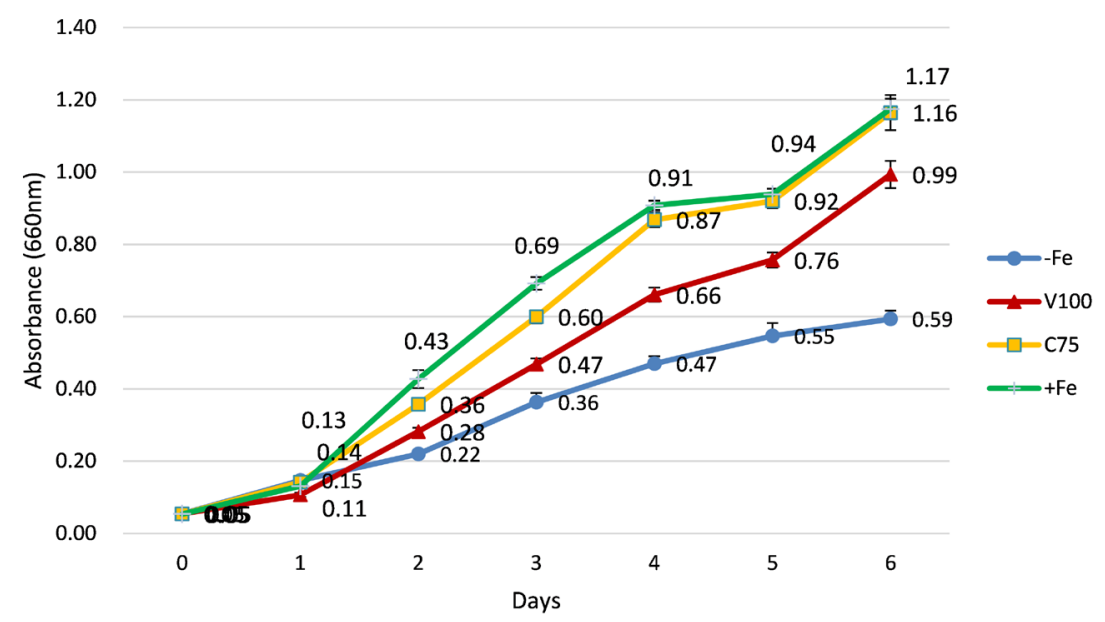

Figure 3. Similarity experiments of phytoplankton productivity under aerobic culture of Chlorella vulgaris with various JM media; with its own $\mathrm{Fe}(+\mathrm{Fe},-+-) \mathrm{HNHC}$, mixture of $75 \%$ clay and $25 \%$ volcanic ash (C75, --) LNHC, fresh $100 \%$ volcanic ash (V100, - $\mathbf{\Delta - )}$

LNLC, without its own Fe (-Fe, - -) HNLC. Standard deviation was expressed by each error bar for three measurements with excellent reproducibility. The $100 \%$ volcanic ash (V100) showed the low growth of phytoplankton, similar to LNLC regions. The base medium without Fe showed the lowest growth, similar to HNLC regions. The present similarity experiments were in good agreement with the phytoplankton productivity of oceanic regions in the sequence of HNHC $>$ LNHC $>$ LNLC $>$ HNLC in Table 1. The present results of bottle experiments showed similar growth patterns of "with iron" $(+\mathrm{Fe})$ and "without iron" (-Fe) in Martin [6].

\subsection{Reaction with Iron and Sulfur Compounds}

$\mathrm{S}$ compounds ( $\mathrm{S}, \mathrm{SO}_{2}, \mathrm{SO}_{3}, \mathrm{H}_{2} \mathrm{~S}, \mathrm{H}_{2} \mathrm{SO}_{4}$, sulfates) induce bio-available $\mathrm{Fe}^{2+}{ }_{\text {aq) }}$ toward rapid black iron sulfide $(\mathrm{FeS})\left(\Delta G_{r}^{\circ}=-1207.719 \mathrm{~kJ} \cdot \mathrm{mol}^{-1}\right.$ between FeOOH and $\left.\mathrm{H}_{2} \mathrm{~S}\right)$ and slow pyrite $\left(\mathrm{FeS}_{2}\right)$ sedimentations $\left(\Delta G_{r}^{\circ}=-30.7648\right.$ between $\mathrm{FeS}$ and $\mathrm{H}_{2} \mathrm{~S}$, and $-30 \mathrm{~kJ} \cdot \mathrm{mol}^{-1}$ between $\mathrm{FeS}$ and $\mathrm{S}^{\circ}$ ) [15] in HNLC regions [16] without releasing $\mathrm{Fe}^{2+}{ }_{(a q)}$ to phytoplankton during pyrite $\left(\mathrm{FeS}_{2}\right)$ formation, except for the iron- and sulfur-oxidizing bacteria such as Acidithiobacillus ferrooxidans, Alicyclobacillus and Sulfobacillu, living in pyrite deposits to metabolize ferrous iron and sulfur and producing sulfuric acid [17]. Therefore, HNLC regions are big reservoirs of $\mathrm{S}$ compounds from volcanic eruptions to induce sedimentary $\mathrm{FeS}$ and $\mathrm{FeS}_{2}$ with Fe-limited oceans. The more $\mathrm{H}_{2} \mathrm{~S}$ is available from $\mathrm{S}$ compounds, the more sedimentation occurs in the forms of $\mathrm{FeS}$ and $\mathrm{FeS}_{2}$ as shown in Figure 4. Therefore, the volcanic eruption enhances the formation of $\mathrm{FeS}$ and $\mathrm{FeS}_{2}$ to be Fe-limited condition of "LC" (low-chlorophyll).

Iron sulfate heptahydrate $\left(\mathrm{FeSO}_{4} \cdot 7 \mathrm{H}_{2} \mathrm{O}\right)$ has been used in the iron fertilization experiments as main source of iron due to its high solubility in water. Each 25 gram was dissolved in two bottles with 1 liter distilled water; one was bubbled with $\mathrm{H}_{2} \mathrm{~S}$ gas (50 ppm, 2 LPM, 30 minutes) while another was kept as blank. Figure 5 showed the pale green color (left) as the control without $\mathrm{H}_{2} \mathrm{~S}$ bubbling while the dark black color (right) as the experiment with $\mathrm{H}_{2} \mathrm{~S}$ bubbling. The sedimentary materials were filtered to analyze by X-ray diffractometer (XRD) 


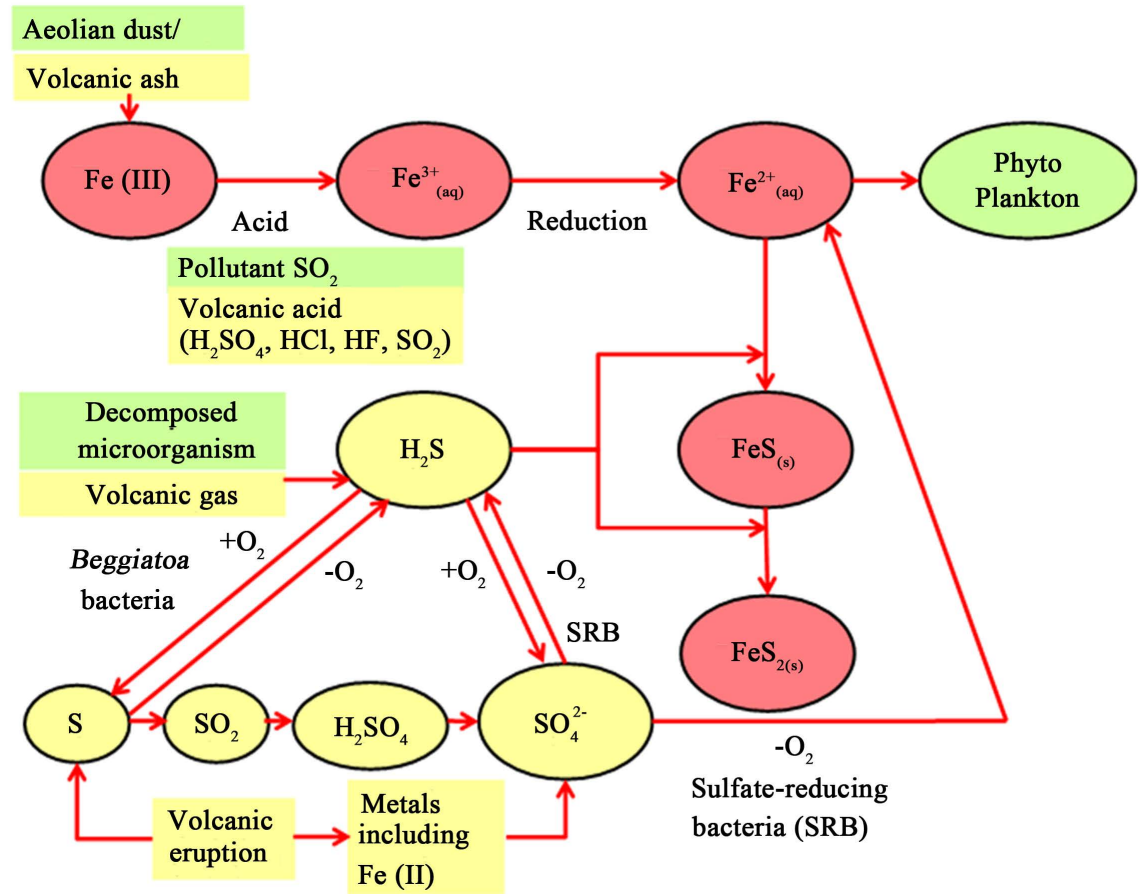

Figure 4. Pathways of Fe from aeolian dust and $\mathrm{S}$ from volcanic eruption prior to being consumed by phytoplankton in HNLC regions. Hydrogen sulfide $\left(\mathrm{H}_{2} \mathrm{~S}\right)$ is produced by 4 routes; volcanic gas $(0.04 \%-0.68 \%)$, sulfur oxidizing bacteria such as Beggiatoa, sulfate reducing bacteria (SRB) such as Desulfovibrio desulfuricans, and decomposed microorganism.

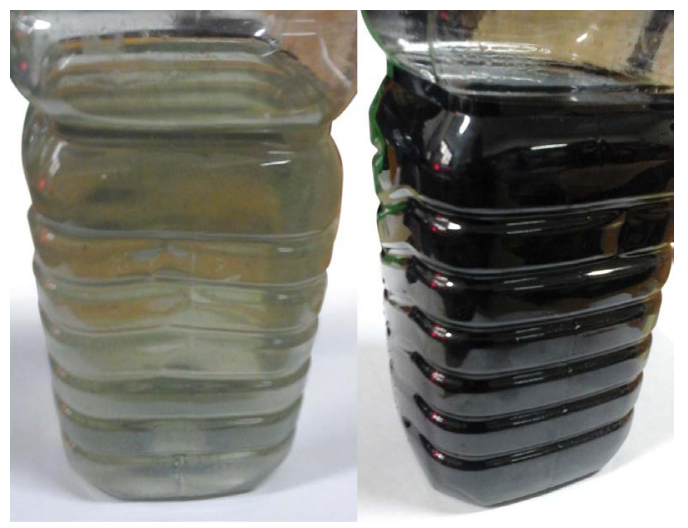

Figure 5. Before (left) and after (right) $\mathrm{H}_{2} \mathrm{~S}$ gas (50 ppm, 2 LPM, 30 minutes) bubbling into distilled water dissolved with $\mathrm{FeSO}_{4} \cdot 7 \mathrm{H}_{2} \mathrm{O}$.

(Model Dmax2500/PC) for the presence of iron sulfides in form of Greigite- $\mathrm{Fe}_{3} \mathrm{~S}_{4}$ among sulfur and iron oxide, as shown in Figure 6. Quantitative analysis of Figure 6 implied that the crystallinity of $\mathrm{Fe}_{3} \mathrm{~S}_{4}$ constituted $4.06 \mathrm{wt} \%$ of total sedimentary materials among amorphous peaks, as shown in Figure 7. It was thus evident that $\mathrm{H}_{2} \mathrm{~S}$ binds $\mathrm{Fe}$ to sediment in black iron sulfide and deprive Fe from the growth of phytoplankton, as shown in Figure 4 and Figure 7. For the improved iron fertilization, it was necessary to avoid the locations with volcanoes for the least sedimentary iron sulfide. 


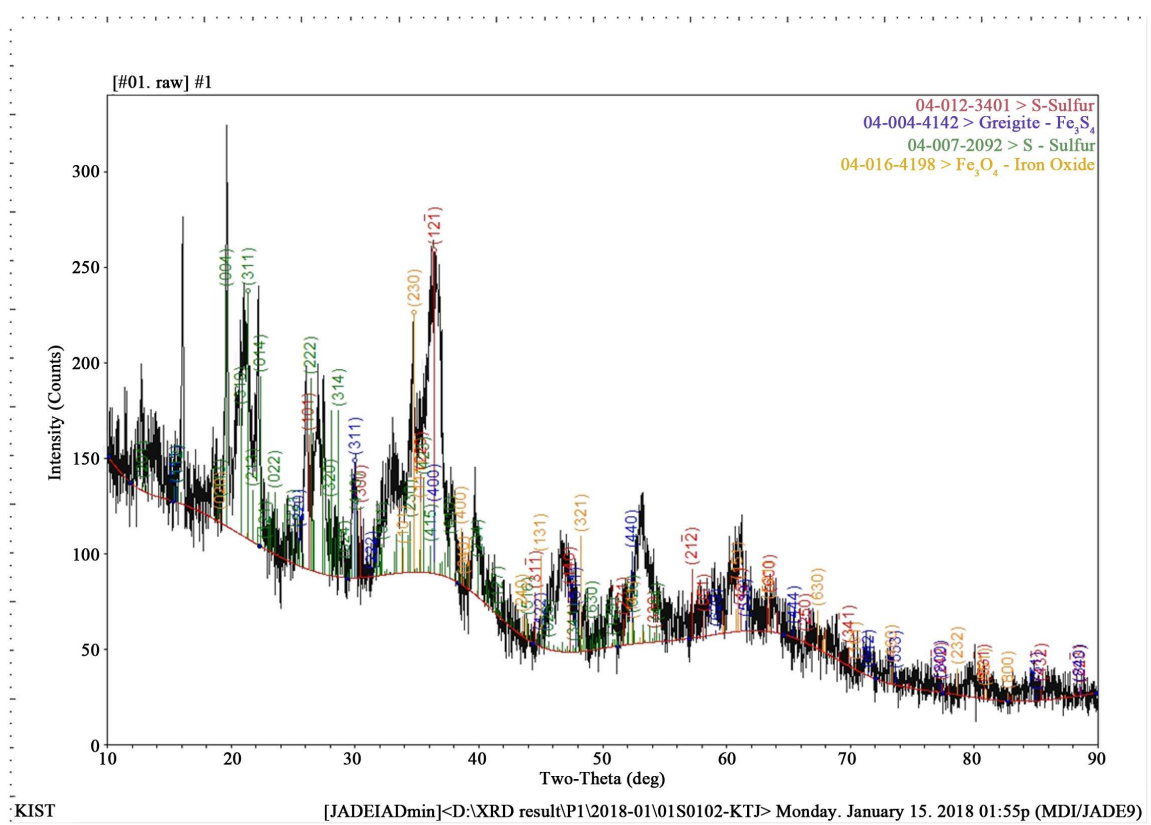

Figure 6. Distribution of XRD pattern for the sedimentary materials induced by the chemical reaction between dissolved $\mathrm{FeSO}_{4} \cdot 7 \mathrm{H}_{2} \mathrm{O}$ and $\mathrm{H}_{2} \mathrm{~S}$ gas bubbling in distilled water.

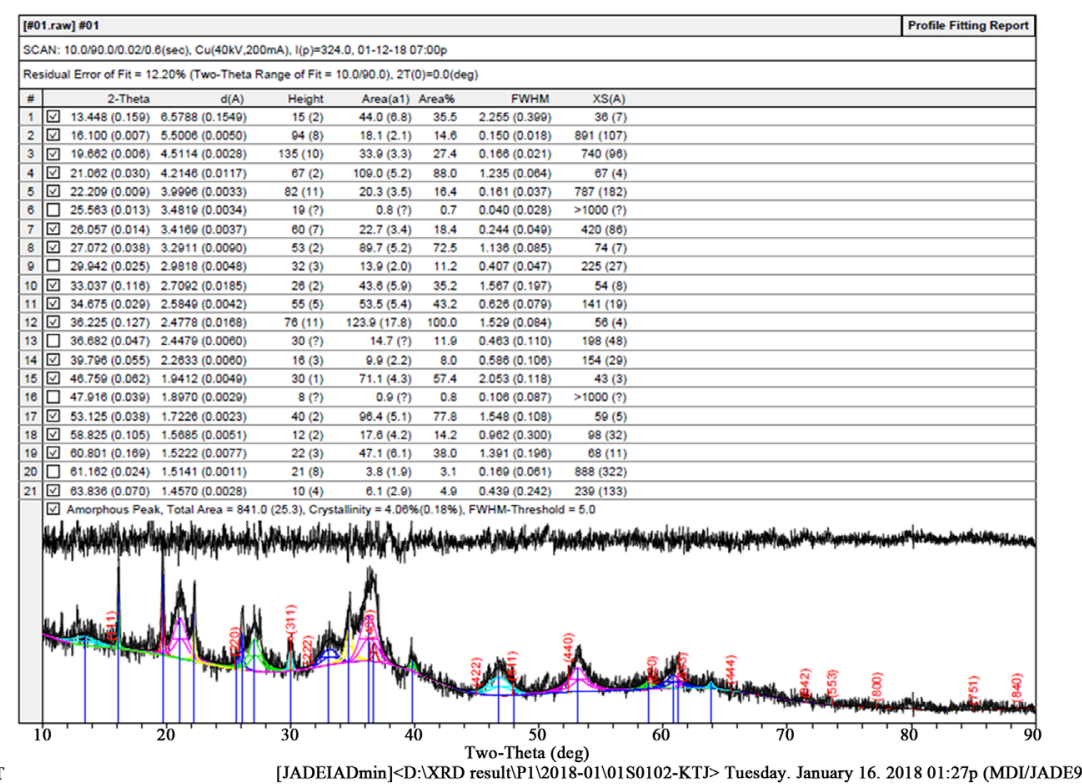

Figure 7. Quantitative analysis of $\mathrm{Fe}_{3} \mathrm{~S}_{4}$ in XRD peaks of $4.06 \mathrm{wt} \%$ induced by the chemical reaction between dissolved $\mathrm{FeSO}_{4} \cdot 7 \mathrm{H}_{2} \mathrm{O}$ and $\mathrm{H}_{2} \mathrm{~S}$ gas bubbling in distilled water.

\subsection{Phytoplankton Productivity with $\mathrm{H}_{2} \mathrm{~S}$}

The effect of S compounds upon the growth of phytoplankton was experimentally examined. $\mathrm{H}_{2} \mathrm{~S}$ generated by the decomposed white of egg was prepared to see its removal of Fe in JM medium with EDTA-Fe as sedimentary iron sulfide (FeS). Figure 8 showed the growth curves of phytoplankton in JM medium with various volumes of the decomposed egg solution. Due to the addition of the decomposed egg solution producing dissolved hydrogen sulfide $\left(\mathrm{H}_{2} \mathrm{~S}\right)$ to the 


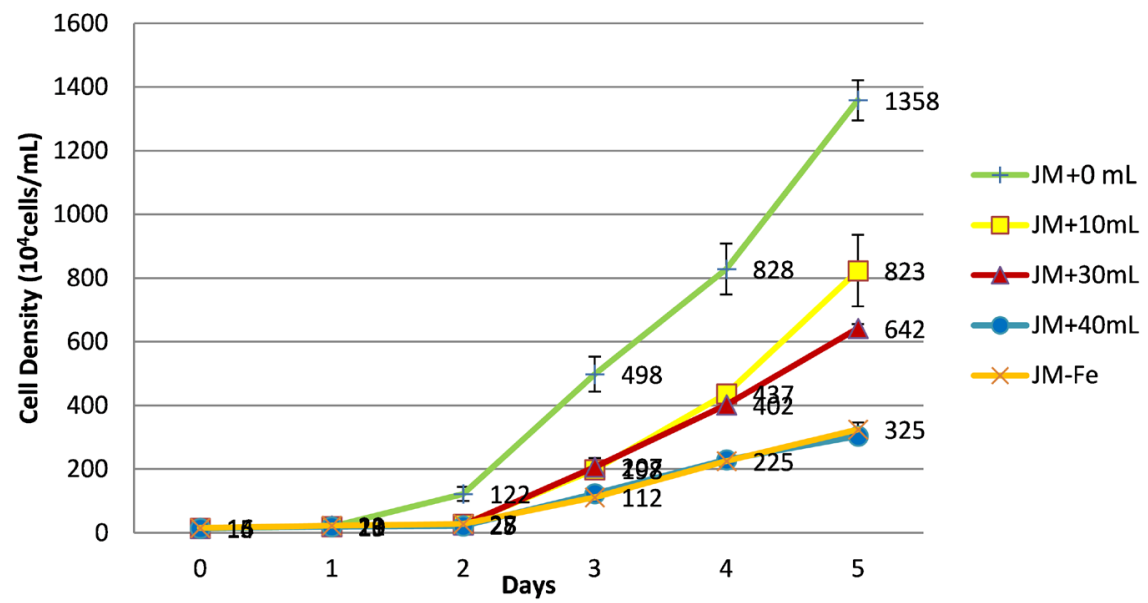

Figure 8. Aerobic culture of Chlorella vulgaris in JM media with various percent volumes of the decomposed egg solution; with its own Fe and without decomposed egg solution $(0 \%)(\mathrm{JM}+0 \mathrm{ml},-+-)$ for the case of HNHC, mixture of $140 \mathrm{ml} \mathrm{JM}$ and $10 \mathrm{ml}$ decomposed egg solution (7\%) (JM + $10 \mathrm{ml}$, --) for the case of LNHC, $120 \mathrm{ml} \mathrm{JM}$ and $30 \mathrm{ml}$ decomposed egg solution (21\%) (JM + $30 \mathrm{ml}$, - $\mathbf{\Delta}-)$ for the case of LNLC, $110 \mathrm{ml} \mathrm{JM}$ and $40 \mathrm{ml}$ decomposed solution (28\%) (JM $+40 \mathrm{ml}$, - - -$)$, and without its own Fe (JM-Fe, -x-) for the case of HNLC.

present JM culture media, cell density in $10^{4}$ cells/ml was measured (Figure 8) by microscope to avoid the problem of turbidity instead of measuring absorbance at $660 \mathrm{~nm}$ (Figure 3). It was evident that the phytoplankton growth was retarded as increasing the volume of decomposed egg solution, generating $\mathrm{H}_{2} \mathrm{~S}$ to remove Fe from JM medium with EDTA-Fe as sedimentary iron sulfide (FeS), from $0 \mathrm{ml}, 10 \mathrm{ml}, 30 \mathrm{ml}, 40 \mathrm{ml}$ among total balanced $150 \mathrm{ml} \mathrm{JM}$ culture media. The highest productivity of phytoplankton was observed when there was no any addition except JM media itself with EDTA-Fe (iron-replenished). As increasing dissolved $\mathrm{H}_{2} \mathrm{~S}$ amounts by increasing the volume of the decomposed egg solution, dissolved $\mathrm{H}_{2} \mathrm{~S}$ reacted with Fe of JM media in EDTA-Fe to sediment as iron sulfide. There was a color change from white of egg solution to dark brown color upon addition of JM media with EDTA-Fe to the decomposed egg solution generating $\mathrm{H}_{2} \mathrm{~S}$. As the volume of decomposed egg solution was reached to $40 \mathrm{ml}$ (28\%), the resultant phytoplankton growth curve was overlapped with the case without its own $\mathrm{Fe}$, which implied that $40 \mathrm{ml}$ decomposed egg solution with dissolved $\mathrm{H}_{2} \mathrm{~S}$ was good enough to deprive all the Fe of remained $110 \mathrm{ml} \mathrm{JM}$ media with EDTA-Fe. Figure 8 clearly indicated that dissolved $\mathrm{H}_{2} \mathrm{~S}$ from the decomposed egg solution reacted with $\mathrm{Fe}$ in JM media to be Fe-limited. The present results of $\mathrm{H}_{2} \mathrm{~S}$ generating egg solution were in good agreement with the phytoplankton growth curves in similarity experiments in Figure 3. Therefore, HNLC regions might be caused by locking iron $(\mathrm{Fe})$ with sulfur $(\mathrm{S})$ compounds including volcanic ash and hydrogen sulfide $\left(\mathrm{H}_{2} \mathrm{~S}\right)$, available from sub-aerial or underwater active volcanoes to form insoluble iron sulfide for Fe-limited low chlorophyll condition. 


\subsection{HNLC Regions}

Characteristics of HNLC regions were well described by high surface nitrate, low DO, high $\mathrm{SO}_{2}$ dispersion and Fe-limited profiles in Figure 9.

$\mathrm{SO}_{2}$ concentration in air over the Sierra Negra Volcano in Galapagos Islands during an eruption in October 2005 showed that $\mathrm{SO}_{2}$ plume (Figure 9(c)) coincides with the surface nitrate (Figure 9(b)), DO at $200 \mathrm{~m}$ (Figure 9(d)), and Fe-limited profiles (Figure 9(e)) in the Equatorial Pacific Ocean. It is thus evident that $\mathrm{SO}_{2}$ dispersion (Figure 9(c)) from sub-aerial volcanoes in tectonic plate boundaries (Figure 9(e) and Figure 9(f)), is linked to not only high nitrate concentration (Figure 9(b)) but also Fe-limitation (Figure 9(e)), which are typical circumstances of HNLC regions. The number of sub-aerial volcanic eruptions and earthquakes are about fifty and millions events every year, respectively, mostly from plate boundaries of 17 major and minor rigid tectonic plates (Figure 9(f)). Volcanoes and earthquakes are generally found where plate boundaries are at the bottom of the oceans; therefore, most volcanic activity is submarine, as seen in black smokers [18] with $\mathrm{SO}_{2}(0.5 \%-11.8 \%)$ and $\mathrm{H}_{2} \mathrm{~S}$ $(0.04 \%-0.68 \%)$. Sulfate reducing bacteria (SRB) produce $\mathrm{H}_{2} \mathrm{~S}$ from sulfate $\left(\mathrm{SO}_{4}^{2-}\right)$ under hypoxic condition while iron reducing bacteria produce $\mathrm{Fe}^{2+}$ from $\mathrm{Fe}_{2} \mathrm{O}_{3} / \mathrm{FeOOH}$ [5]. The resulting chemical reaction occurred around submarine volcanoes is iron sulfides $\left(\mathrm{FeS} / \mathrm{FeS}_{2}\right)$ particles which eventually sunk at the deep sea and ultimately buried in the sea floor. The Subarctic Pacific Ocean, one of the large HNLC regions, is surrounded by many active volcanoes. In the Aleutian chains, Pavlof has erupted 40 times since 1700's and continue till today; Cleveland erupted 19 times since 1980's and continue today [19] while Mt. Kasatochi erupted most recently in 2008. Augustine volcanoes have erupted 14 times since 230 and more recently in 2005, and volcanoes in the Cook Inlet area (e.g., Katmari, Redoubt, St. Augstine, Crater Peack, Spurr) have erupted every 10 - 35 years during the $20^{\text {th }}$ century [20]. Besides, the heavy yearly rainfall (more than $2000 \mathrm{~mm}$ a year) in the Gulf of Alaska may enhance the effective removal of atmospheric $\mathrm{SO}_{2}$ dispersion from volcanic plume into the Gulf of Alaska. Therefore, the Subarctic Pacific HNLC region appears to be driven by such volcanic eruptions for at least during the last few hundred years. The Southern Ocean is also surrounded by many active volcanoes. Mt. Erebus belonging to the McMurdo Volcanic Group in Ross Island, Antarctica, [21], has erupted continuously since 1972. More than 26 active and extinct volcanoes in Peru and Chile, 50 plus eruptions in Galapagos Islands during the last 200 years, 10 volcanoes with recent eruption of Cotopaxi in Ecuador, surround the South Pacific Ocean and Equatorial Pacific. Sulfur compounds emitted from active volcanoes are carried away by prevailing winds and deposited on the sea surface. Such volcanic sulfur compounds deposit over the ocean area may induce the formation of three different HNLC regions, as can be observed from the dissolved Fe distribution of Figure 9(e) and summarized in Table 3. 


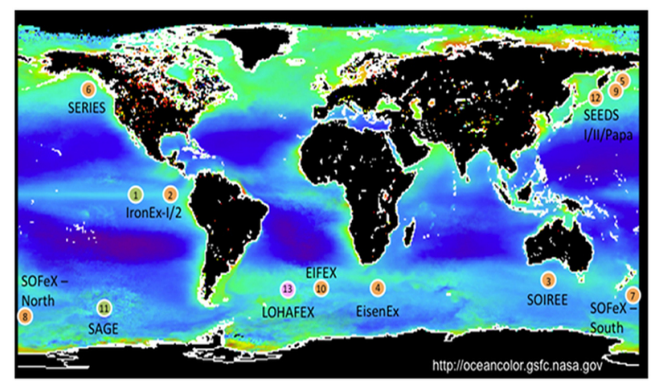

(a)

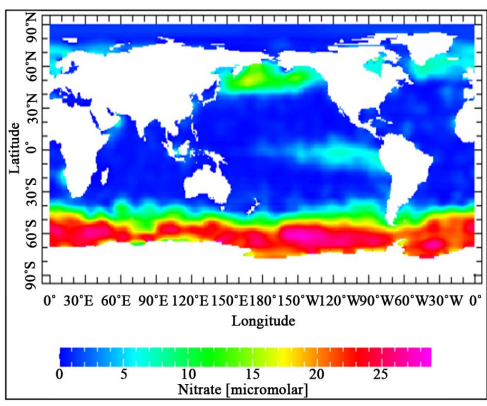

(b)

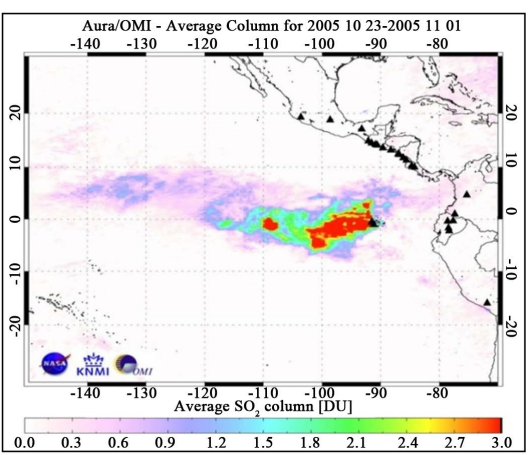

(c)

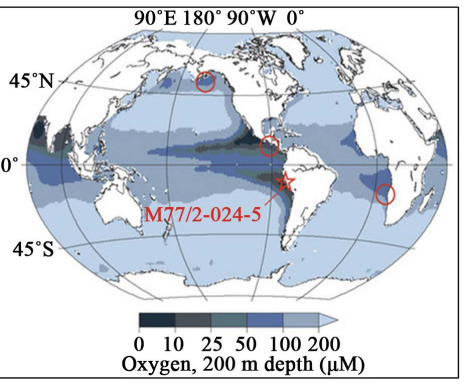

(d)

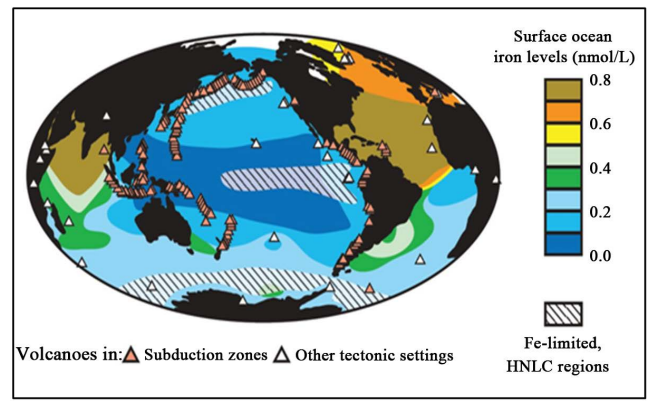

(e)

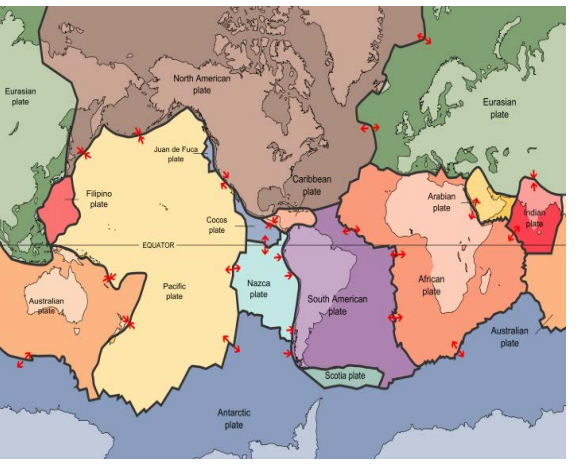

(f)

Figure 9. Global distribution maps associated with HNLC regions: (a) Locations of iron fertilization till the present detailed in Table 4 [22]; (b) Surface ocean nitrate concentrations [23]; (c) Sulfur dioxide concentration over the Sierra Negra Volcano, Galapagos Islands during an eruption in October 2005 [24]; (d) Concentration of dissolved oxygen [25]; (e) Surface ocean iron-concentrations, location of Fe-limited HNLC regions and sub-aerially active volcanoes in subduction zones and other tectonic settings [13]; and (f) Major tectonic plates on earth [26].

\subsection{Previous 14 Iron Fertilization Experiments}

The previous 14 iron enrichment experiments on mesoscale size since IronEx I of 1993 till Haida Gwaii of 2012 (Table 3) have commonly shown short-term impacts on the sequestration of atmospheric $\mathrm{CO}_{2}$ due to their inappropriate locations near or on the streamlines of high $\mathrm{SO}_{2}$ (Figure $9(\mathrm{c})$ ), low DO (Figure 9(d)), near active volcanoes (Figure 9(e) and Table 3 ), and tectonic plate boundaries (Figure 9(f) and Table 3). It was thus very important to choose the location of the iron fertilization, not too close to the source of sulfur (S) compounds such as volcanoes, earthquakes, and boundaries of tectonic plates. A 
Table 3. Sink, carriers and sources of sulfur (S) compounds and iron (Fe) in HNLC regions.

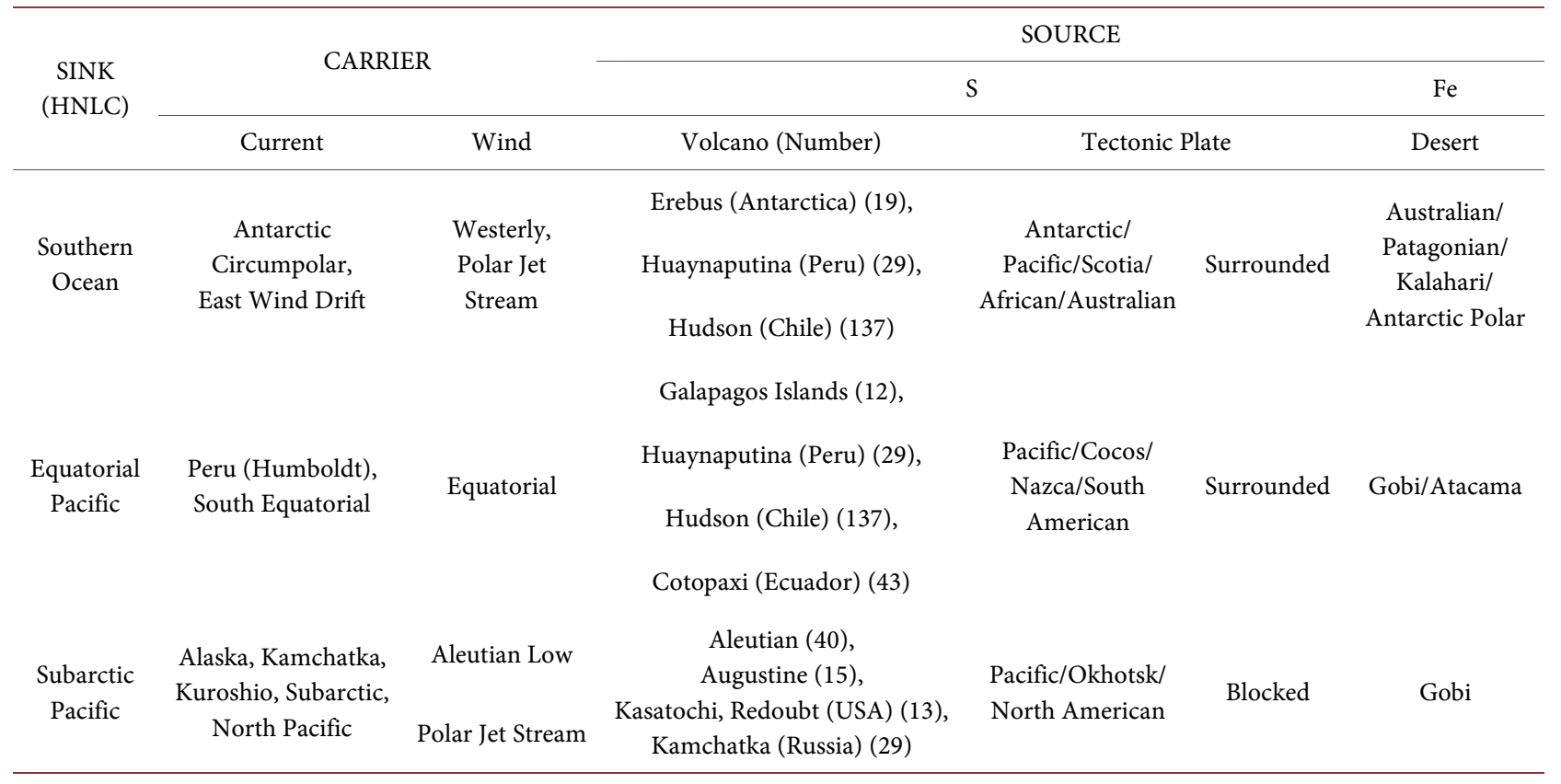

global distribution of oceanic dissolved oxygen (DO) (Figure 9(d)) showed that DO in the Equatorial Pacific was low while that of the Southern Ocean was high. Since $\mathrm{SO}_{2}$ reacts with $\mathrm{DO}$ and becomes $\mathrm{H}_{2} \mathrm{SO}_{4}$ and sulfates with consumption of DO, the distribution map of DO or $\mathrm{O}_{2}$ (Figure $9(\mathrm{~d})$ ) is then the opposite as that of $\mathrm{SO}_{2}$ (Figure $9(\mathrm{c})$ ). That is, if a region contains low DO, then such a region has high $\mathrm{SO}_{2}$ due to the neighboring active volcanoes. Therefore, $\mathrm{SO}_{2}$ emissions from Galapagos Islands (Figure 9(c)), mountains of Peru, Ecuador and Chile showed long dispersing tails same patterns as those of nitrate (Figure 9(b)) and Fe-limited HNLC regions (Figure 9(e)) with low profiles of DO (Figure 9(d)) in the Equatorial Pacific. Since the Southern Ocean flows very fast $\left(v=4 \mathrm{~km} \cdot \mathrm{h}^{-1}\right)$, its mass flow rate $\left(C_{A} \cdot Q_{A}\right)$ enriched with fresh air of $20.9 \% \mathrm{O}_{2}\left(C_{A}\right)$ by westerly winds and Polar Jet Stream contains abundant DO due to rapid mixing of water by Antarctic Circumpolar Current.

Most of $\mathrm{SO}_{2}\left(C_{A}\right)$ from yearly continuous volcanic eruptions at Mt. Erebus of the Antarctic are quickly dissipated at the deep ocean of the Southern Ocean due to its enormous amount of oceanic volumetric flow rate $\left(1.3 \times 10^{8} \mathrm{~m}^{3} \cdot \mathrm{sec}^{-1}, Q_{A}\right)$ of water causing much higher mass flow rate $\left(\dot{m}_{A}=C_{A} \cdot Q_{A}\right)$ of $\mathrm{SO}_{2}$ dissolution and subsequently locking volcanic sulfur compounds, as observed in the oxygen minimum zones $(\sim 1100 \mathrm{~m})$ of the abundant $\mathrm{H}_{2} \mathrm{~S}$ pool $(\sim 150 \mu \mathrm{M})$ [16]. Since the Southern Ocean is analogous to the system of continuously stirred tank reactor (CSTR) with high revolution agitator $\left(v=4 \mathrm{~km} \cdot \mathrm{h}^{-1}\right)$ to have a uniform distribution of volcanic sulfur compounds throughout the Antarctic Circumpolar Current (ACC) with limited leakage to outside, the concentrations of nitrate (Figure 9(b)) and DO (Figure 9(d)) are the highest among 3 HNLC regions.

Although the aeolian dust over continents carry abundant iron $(\mathrm{Fe})(3.5-6.0$ 
wt $\%$ or 7.0 - 18.0 wt\% clay in Tasmania of Australia) to HNLC regions, most of them are sedimented out from the upper surface waters as insoluble iron sulfides ( $\mathrm{FeS} / \mathrm{FeS}_{2}$ ) with reaction of sulfur compounds ( $\mathrm{S}, \mathrm{SO}_{2}, \mathrm{SO}_{3}, \mathrm{H}_{2} \mathrm{~S}, \mathrm{H}_{2} \mathrm{SO}_{4}$, sulfates) in the ocean, available from volcanic eruptions either in submarine or in air, while only negligible amounts of iron $\left(1 \times 10^{-8} \%\right)\left\{=\left(4 \times 10^{-6} \mathrm{ppm} / 3.5 \times 10^{4}\right.\right.$ ppm $) \times 100)\}$ are available in HNLC regions, assuming $4 \times 10^{-6} \mathrm{ppm} \mathrm{Fe}(0.07$ nmol L $\left.{ }^{-1}\right)$ [22] out of $3.5 \%\left(=3.5 \times 10^{4} \mathrm{ppm}\right)$ Fe supply by aeolian dust. The present study suggests that HNLC regions (Figure 9 (b) and Table 3 ) could be simultaneously formed due to the following reasons; 1) Blocked (Southern Ocean and Subarctic Pacific) or surrounded (Equatorial Pacific) by tectonic plates (Figure 9(f)), whose boundaries emit volcanic sulfur compounds (Figure $9(c))$ to form iron sulfides. The iron sulfide particles are subsequently sunk to the deep waters (Figure $9(\mathrm{e})$ ), 2) Located in the downwind or stream of volcanoes (Figure $9(\mathrm{c})$ ), 3) Located far from continents to take river/bottom sediments except the Subarctic Pacific, 4) Mimic aeolian dust inputs $\left(4 \mathrm{~g} \cdot \mathrm{m}^{-2} \cdot \mathrm{yr}^{-1}\right.$ for Southern Ocean, 7 for Equatorial Pacific, and 14 for Subarctic Pacific) [11], and 5) Isolated (Southern Ocean and Subarctic Pacific) from neighboring Oceans by currents and winds, as summarized in Table 3. The locking and eventual removal of Fe by volcanic S compounds may have resulted in nutrient-enriched but Fe-limited HNLC regions while other oceanic regions maintain high chlorophyll with less accumulation of major nutrients $(\mathrm{N}, \mathrm{P}, \mathrm{Si})$.

Although 14 iron fertilization experiments during the last 24 years have been conducted [22] including LOHAFEX in 2009 [27] and Haida in 2012 [11] (Table 4), such experiments (Figure 9(a)) have never been conducted at location that is free from serial volcanic eruptions in the recent 74 years for the removal of volcanogenic sulfur (see Figure 2).

\subsection{Improved Iron Fertilization Experiment}

The sulfate concentration increased horizontally towards the volcanic source [28]. Vertical profile of $\mathrm{O}_{2}$ at the southern Omani coast with seasonal HNLC characteristics showed severely $\mathrm{O}_{2}$-depleted waters $\left(\mathrm{DO}<0.2 \mathrm{mg} \cdot \mathrm{l}^{-1}, \sim 9 \mu \mathrm{M} \mathrm{O}_{2}\right.$ ) from $170 \mathrm{~m}$ to $1000 \mathrm{~m}$ depth due to extensive consumption of DO in waters by the volcanic S compounds, while minimum limit of dissolved oxygen content for living fish of about $5 \mathrm{mg} \cdot \mathrm{l}^{-1} \mathrm{DO}\left(156 \mu \mathrm{M} \mathrm{O}_{2}\right)$ was available from its oceanic surface to $80 \mathrm{~m}$ depth [9]. Thus, the volcanic S compounds deposited on the surface ocean of HNLC regions appear to dissolve their S compounds extensively at the depth range of $170 \mathrm{~m}$ and $1000 \mathrm{~m}$ where phytoplankton cannot live due to toxic volcanic chemicals $\left(\mathrm{SO}_{2}, \mathrm{H}_{2} \mathrm{~S}, \mathrm{HCl}, \mathrm{HF}, \mathrm{H}_{2} \mathrm{SO}_{4}\right)$ [29] in waters. In contrast, the concentration of diatom Pseudonitzschia was maximal between 45 to $80 \mathrm{~m}$ (or upper $80 \mathrm{~m}$ ) depth in HNLC region [30]. Therefore, Fe-replete composite should be made using Fe-enriched natural clays (7\% - 18\% Fe in west Australia) or aged (more than 74 years) desulfurized volcanic ashes while the target sea area should be $\mathrm{O}_{2}$-enriched upper $80 \mathrm{~m}$ layer of the surface ocean with buoyant carriers so as to be assimilated to phytoplankton community. 
Table 4. Previous iron fertilizations with location, tectonic plate, and volcano.

\begin{tabular}{|c|c|c|c|c|}
\hline Experiment & Date & Location & Tectonic Plate & Volcano (Number) \\
\hline IronEx I & (Month/Year) & $5^{\circ} \mathrm{S}, 90^{\circ} \mathrm{W}$ & Pacific/Nazca & Galapagos Islands (12) \\
\hline IronEx II & June 1995 & $4^{\circ} \mathrm{S}, 107^{\circ} \mathrm{W}$ & Pacific/Nazca & $\begin{array}{l}\text { near Seamount A at } \\
\text { East Pacific Rise }\end{array}$ \\
\hline SOIREE & February 1999 & $61^{\circ} \mathrm{S}, 140^{\circ} \mathrm{E}$ & Antarctic/Australian & Erebus (19) \\
\hline EisenEx & November 2000 & $48^{\circ} \mathrm{S}, 21^{\circ} \mathrm{E}$ & Antarctic/African & $\begin{array}{c}\text { Erebus }(19) / \text { near } \\
\text { Marion at African Plate }\end{array}$ \\
\hline SEEDS I & July 2001 & $48.5^{\circ} \mathrm{N}, 164.5^{\circ} \mathrm{E}$ & Pacific/Okhotsk & Kamchatka Peninsula (29) \\
\hline SOFEX-N & January 2002 & $55^{\circ} \mathrm{S}, 172^{\circ} \mathrm{W}$ & Pacific/Antarctic & Erebus (19) \\
\hline SOFEX-S & March 2002 & $66^{\circ} \mathrm{S}, 172^{\circ} \mathrm{W}$ & Pacific/Antarctic & Erebus (19) \\
\hline SERIES & July 2002 & $51^{\circ} \mathrm{N}, 144.5^{\circ} \mathrm{W}$ & $\begin{array}{l}\text { Pacific/North } \\
\text { American }\end{array}$ & Augustine (15) \\
\hline EIFEX & February 2004 & $50^{\circ} \mathrm{S}, 2^{\circ} \mathrm{E}$ & $\begin{array}{c}\text { Antarctic/ } \\
\text { South American }\end{array}$ & $\begin{array}{c}\text { Erebus (19)/near Bouvet } \\
\text { at African Plate }\end{array}$ \\
\hline SAGE & March 2004 & $46.5^{\circ} \mathrm{S}, 172.5^{\circ} \mathrm{E}$ & Pacific/Australian & $\begin{array}{l}\text { Erebus (19)/near Chatham } \\
\text { Islands with volcanic ash } \\
\text { from Taupo Volcanic Zone }\end{array}$ \\
\hline FeeP & July 2008 & $27.6^{\circ} \mathrm{N}, 22.4^{\circ} \mathrm{W}$ & African/Eurasian & $\begin{array}{l}\text { near El Hierro of } \\
\text { Canary Islands }\end{array}$ \\
\hline SEEDS II & July 2004 & $48^{\circ} \mathrm{N}, 166^{\circ} \mathrm{E}$ & Pacific/Okhotsk & Kamchatka Peninsula (29) \\
\hline LOHAFEX & March 2009 & $48^{\circ} \mathrm{S}, 16^{\circ} \mathrm{E}$ & Antarctic/African & $\begin{array}{c}\text { Erebus }(19) / \text { near } \\
\text { Marion/Bouvet at } \\
\text { African Plate }\end{array}$ \\
\hline Haida Gwaii & July 2012 & $52.7^{\circ} \mathrm{N}, 139.3^{\circ} \mathrm{W}$ & $\begin{array}{l}\text { Pacific/North } \\
\text { American }\end{array}$ & Bowie Seamount \\
\hline
\end{tabular}

Fourteen previous iron enrichment experiments from IronEx I in 1993 to Haida Gwaii in 2012 have been conducted by dumping a few hundred tons of $\mathrm{Fe}$ in form of $\mathrm{FeSO}_{4}$. The previous iron fertilizations (Figure 9(a) and Table 4) were located near subaerial and underwater volcanoes in the divergent boundaries of tectonic plates (Figure 9(c) and Figure 9(e); Table 4). The Ring of Fire is an area in the basin of the Pacific Ocean where a large number of volcanoes and tectonic plate boundaries are present (Figure 9(e) and Figure 9(f)). Therefore, the prospective iron fertilization experiment is recommended to be conducted far from sulfur sources such as volcanoes and boundaries of tectonic plates, not only to minimize the iron consumption by the chemical formation of sedimentary $\mathrm{FeS}$ and $\mathrm{FeS}_{2}$ due to the volcanic $\mathrm{S}$ compounds, but also to maximize the availability of dissolved Fe to phytoplankton. The dissolved Fe is engulfed by cyanobacteria (the diazotrophs Trichidesmium and Crocosphaera Watsonii, and the non-diazotrophs Synechococcus and Prochlorococcus) to be grazed by diatoms and subsequently by copepods, krill, and small fish or humpback whale. Humpback whale has been observed in seven HNLC regions of the Subarctic Pacific (Alaska) and the Equatorial Pacific (Galapagos) with five areas in the 
Southern Ocean (Bransfield Strait, Gerlache Strait, South Georgia, Crozet, Kerguelen), four LNLC regions of Iceland (Snaefellsnes Peninsula), Japan (Zama$\mathrm{mi}$ ), Guam, and Hawaii (Maui), five coastal upwelling HNHC regions (Benguela, Canary, California-Monterey Bay, Humboldt-Galapagos, Somali), and eight hot fishery oceans of LNHC regions in Table 3. However, five locations in the Southern Ocean (Bransfield Strait, Gerlache Strait, South Georgia, Crozet, Kerguelen) were more prospective ones due to their iron availabilities from upwelling and hydrothermal vent [16] with enriched nutrients and high mass flow rate of ACC for wide natural bloom area during warm austral summer [31]. Shag Rocks $\left(53^{\circ} \mathrm{S}, 42^{\circ} \mathrm{W}\right)$ of South Georgia in Scotia Sea appeared to be the most prospective location for the following reasons. 1) Not over the tectonic plate boundary, but just outside of the northern Scotia plate [32] and far from volcanoes. 2) Located in the downwind region of near Patagonian Fe-rich desert (800 $\mathrm{km}$ distanced) [33] and rocky islands covered with nutrient-enriched ice melt. 3) Cold Weddell Sea Deep Water meets with nutrient warm waters of the Subantarctic upwelling, providing ACC with high flow velocity $\left(\sim 4 \mathrm{~km} \cdot \mathrm{h}^{-1}, v\right)$ and the largest current $\left(125 \times 10^{6} \mathrm{~m}^{3} \cdot \mathrm{s}^{-1}, Q\right)$ for fast deployment of Fe-replete composite $\left(m_{A}\right)$ or $\left(C_{A}\right)$ over a wide oceanic bloom area $\left(\sim 145,000 \mathrm{~km}^{2}\right)$ [34] with high momentum $\left(m_{A} \cdot v\right)$ and high mass flow rate $\left(\dot{m}_{A}=C_{A} \cdot Q\right)$, and full depth vertical fields with $100 \mathrm{~m}$ plateau and $3500 \mathrm{~m}$ deep water of Southern ACC Front [35] to induce nutrient-enriched upwelling, as observed in Crozet Islands and Kerguelen Plateau in the Southern Ocean [36]. 4) High nitrate (22 - $29 \mu \mathrm{M})$ and chlorophyll $\left(0.46-0.93 \mu \mathrm{g} \cdot \ell^{-1}\right)$ [17] with ACC dominated by diatoms and Weddell Sea Deep Water dominated by coccolithophorids and silicoflagellates passing through, located at the South of the Polar Front dominated by diatoms, and high concentrations of silica for diatoms are available. 5) Located not far (185 $\mathrm{km})$ from South Georgia Island $(170 \times 40 \mathrm{~km})$ which is the unique position inside the Antarctic Convergence yet outside the limit of the yearly sea ice to be home to tens of millions of breeding penguins, 300,000 elephant seals, 3 million fur seals, and 25 species of breeding birds, implying its good location for phytoplankton productivity. 6) Located not far from the used whale station of Grytviken in South Georgia, which had been open in 1904 but closed in 1966 due to diminishing whale population. Since there are still massive elephant seals, fur seals, and king penguins at Grytviken but no humpback whales around, Grytviken can be a good base camp for the iron fertilizing ships and their crew residence not for several weeks, as commonly done in the previous 14 mesoscale iron fertilizations, but for several months or even years to observe the Fe stimulated phytoplankton productivity such as the return of humpback whales as biomarkers for the improved iron fertilization.

\subsection{Data Analysis for Grazing Control in HNLC Regions}

The substitution of ferredoxin by flavodoxin, the use of plastocyanin instead of cytochrome $b f$ and a variant stoichiometry of photosynthetic complexes are 
notable adaptive strategies to facilitate diatom growth in low-iron condition [37]. Diazotroph Trichodesmium required iron to form the enzyme nitrogen (nitrogenase) for fixation of $\mathrm{N}_{2}$ as much as 465 molar ratio of $\mathrm{N} / \mathrm{Fe}$ while 5,000 for diatoms in nitrate (nitrate reductase) and 16,000 for flagellates in ammonium (nitrite reductase) [38]. With assumption of $100 \%$ Fe by Trichodesmium for $\mathrm{N}_{2}$-fixation, it was evident that diatom took $9 \% \mathrm{Fe}\left(=\frac{465}{5000} \times 100\right)$ and flagellates took $3 \% \mathrm{Fe}\left(=\frac{465}{16000} \times 100\right)$ as illustrated in Figure 10. Therefore, diatoms took $109 \%$ iron if diatoms $(9 \% \mathrm{Fe})$ graze Trichodesmium $(100 \% \mathrm{Fe})$ in HNLC regions. Dinoflagellate Gymnodium breve had $K_{s}=7.2 \mu \mathrm{mol} \quad \mathrm{NO}_{3}^{-} \quad \mathrm{kg}^{-1}$ while diatoms had $K_{s}=1.3 \mu \mathrm{mol} \mathrm{NO}_{3}^{-} \mathrm{kg}^{-1}$, which implied that $\mathrm{NO}_{3}^{-}$was mainly consumed by diatoms rather than by dinoflagellates [38]. These observations might be one of reasons why diatoms are dominant at high $\mathrm{NO}_{3}^{-}$and low $\mathrm{Fe}$ levels in HNLC regions.

Diatoms are important primary producers $(>40 \%)$ in the ocean with a high sinking velocity of $0.96 \mathrm{~m} \cdot \mathrm{d}^{-1}$ for large centric diatoms [39]. Diatoms by cheap (8\%) energy requirement with genetically adapted system in HNLC regions [40] are capable of dividing at any point of the diel cycle, which are preferably fed by copepods and krill during the night. The depth of the iron enrichment experiment should be within the top $80 \mathrm{~m}$ layer where diatoms [41], krill and humpback reside together while copepods live deeper to escape from krill with inverse relationship between krill and copepods abundances [42]. In the present analysis of the experimental data [43] in 2000 EisenEx Experiment conducted in the Southern Ocean $\left(21^{\circ} \mathrm{E}, 48^{\circ} \mathrm{S}\right)$ in Table 4 , the unsteady state mass balance of diatoms in a controlled patch volume is given by:

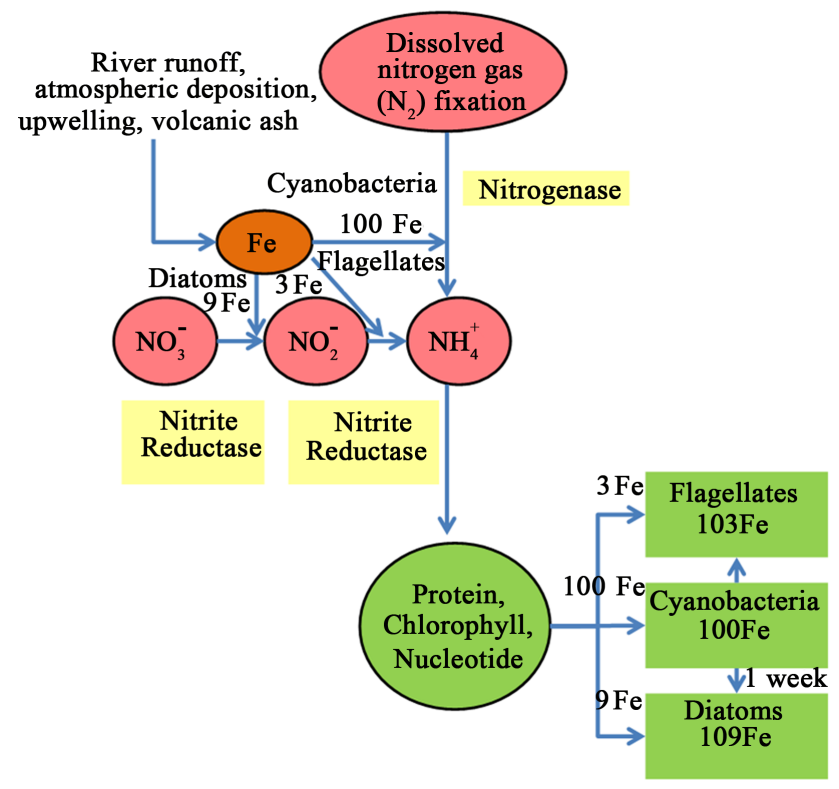

Figure 10. Relative uptake percentage of required iron for the syntheses of cyanobacteria, diatoms, and flagellates with corresponding nitrogen enzymes. 


$$
\frac{\mathrm{d} X_{d}}{\mathrm{~d} t}=\left(\dot{X}_{d}\right)_{\text {in }}-\left(\dot{X}_{d}\right)_{\text {out }}+\mu_{d}-\left(\mathcal{U}_{c}+\mathcal{U}_{k}\right)
$$

where $\left(\dot{X}_{d}\right)_{i n}=$ diatoms input rate,

$\left(\dot{X}_{d}\right)_{\text {out }}=$ diatoms output rate,

$X_{d}=$ concentration of diatoms in patch at time $t$ of days since the first rion fertilization,

$\mu_{d}=$ growth rate of diatoms,

$u_{c}=$ diatoms loss rate by copepods,

$u_{k}=$ diatoms loss rate by krill.

If diatoms input rate was close to diatoms output rate in a controlled patch volume,

$$
\begin{gathered}
\left(\dot{X}_{d}\right)_{\text {in }} \approx\left(\dot{X}_{d}\right)_{\text {out }} \\
\therefore \frac{\mathrm{d} X_{d}}{\mathrm{~d} t}=\mu_{d}-\left(\mathcal{U}_{c}+\mathcal{U}_{k}\right)
\end{gathered}
$$

According to the definition [44],

$$
\mu_{d}=\frac{1}{X_{d}} \frac{\mathrm{d} X_{d}}{\mathrm{~d} t}=\frac{\mathrm{d} \ln X_{d}}{\mathrm{~d} t}
$$

If assuming that copepods and krill were grown by their grazing diatoms, diatoms loss rates by copepods and krill could be similarly defined as,

$$
\begin{gathered}
\mathcal{U}_{c}=\frac{\mathrm{d} \ln X_{c}}{\mathrm{~d} t} \\
\mathcal{U}_{k}=\frac{\mathrm{d} \ln X_{k}}{\mathrm{~d} t} \\
\therefore \frac{\mathrm{d} X_{d}}{\mathrm{~d} t}=\frac{\mathrm{d} \ln X_{d}}{\mathrm{~d} t}-\left(\frac{\mathrm{d} \ln X_{c}}{\mathrm{~d} t}+\frac{\mathrm{d} \ln X_{k}}{\mathrm{~d} t}\right)
\end{gathered}
$$

Thus,

$$
\mathrm{d} X_{d}=\mathrm{d} \ln X_{d}-\left(\mathrm{d} \ln X_{c}+\mathrm{d} \ln X_{k}\right)
$$

By integration,

$$
\therefore X_{d}=k+\ln \left(\frac{X_{d}}{X_{c} \cdot X_{k}}\right)
$$

where $k=X_{d o}+\left(\ln \frac{X_{c o} \cdot X_{k o}}{X_{d o}}\right)$.

$X_{d}=$ concentration of diatoms in patch at time $t$ of days since the first iron fertilization,

$X_{c}=$ concentration of copepods in patch at time $t$ of days since the first iron fertilization,

$X_{k}=$ concentration of krill in patch at time $t$ of days since the first iron fertilization,

$k=$ initial constant, 
$X_{d o}=$ initial concentration of diatoms in patch,

$X_{c o}=$ initial concentration of copepods in patch,

$X_{k o}=$ initial concentration of krill in patch.

There could be 3 special cases at steady state such that the apparent diatoms growth rate was greater, equal and less than grazing loss rates by both of copepods and krill. For simplicity, let's took the second case that the apparent diatoms growth rate was equal to grazing loss rates by copepods and krill as below.

$$
\begin{gathered}
\mu_{d}=\mathcal{U}_{c}+\mathcal{U}_{k} \\
\frac{\mathrm{d} \ln X_{d}}{\mathrm{~d} t}=\frac{\mathrm{d} \ln X_{c}}{\mathrm{~d} t}+\frac{\mathrm{d} \ln X_{k}}{\mathrm{~d} t} \\
\therefore \mathrm{d} \ln X_{d}=\mathrm{d} \ln \left(X_{c} \cdot X_{k}\right)
\end{gathered}
$$

Since there was the inverse relationship between copepods and krill abundances [44], it could be denoted as,

$$
X_{c}=\frac{c_{1}}{X_{k}}
$$

where $c_{1}=$ inversely proportional constant between copepods and krill.

$$
\therefore \mathrm{d} \ln X_{d}=\mathrm{d} \ln c_{1}
$$

By integration,

$$
\ln \left(\frac{X_{d}}{X_{d o}}\right)=c_{2}
$$

where $c_{2}=$ integration constant

$$
\therefore X_{d}=X_{d o} \cdot \mathrm{e}^{C_{2}}
$$

If we wanted to sequester the atmospheric $\mathrm{CO}_{2}$ by the efficient growth rate of diatoms with iron enrichment, we had to keep the concentrations of diatoms after the iron fertilization $\left(X_{d}\right)$ to be greater than concentrations of diatoms before the iron fertilization $\left(X_{d o}\right)$ with the constraint as,

$$
\therefore X_{d}>X_{d o} \cdot \mathrm{e}^{C_{2}}
$$

If the grazing rate $\mathcal{U}$ was slightly modified from previous definition as,

$$
\mathcal{U}=F\left(\frac{n}{V}\right)
$$

where $F=$ clearance rate $\left(\mathrm{ml} \cdot \mathrm{ind}^{-1} \cdot \mathrm{h}^{-1}\right)$,

$n=$ number of grazers (ind),

$V=$ experimental volume $(\mathrm{ml})=S \cdot H$,

$S=$ experimental surface area $\left(\mathrm{m}^{2}\right)$,

$H=$ upper $150 \mathrm{~m}$ of the water column [43].

From Table 1 in Manuscript 1 [43], copepods standing stocks were 57,755 for $>2 \mathrm{~mm}$ and 180,730 for $1-2 \mathrm{~mm}$ with resultant sum of 238,485 (ind. $\mathrm{m}^{-2}$ ) at 7 days since the first iron fertilization in patch. Thus,

$$
\left(\frac{n}{V}\right)=\left\{\frac{(n)}{S}\right\}\left(\frac{1}{H}\right)=\frac{238485 \mathrm{ind} \cdot \mathrm{m}^{-2}}{150 \mathrm{~m}}=1590 \mathrm{ind} \cdot \mathrm{m}^{-3}
$$


From Table 4 in Manuscript 1 [43], clearance rates inside the fertilized patch were given by, Calanus simillimus (12.4 in day 8), Rhincalanus gigas (7.7 in day $16)$, and copepods $<2 \mathrm{~mm}(0.2$ in day 7$)$, whose sum was $20.3\left(\mathrm{ml} \cdot \mathrm{ind}^{-1} \cdot \mathrm{h}^{-1}\right)$.

Therefore, the grazing rate by copepods, $\mathcal{U}_{c}$, was given by,

$$
\begin{gathered}
\mathcal{U}_{c}=F\left(\frac{n}{V}\right)=\left(20.3 \mathrm{ml} \cdot \text { ind }^{-1} \cdot \mathrm{h}^{-1}\right)\left(1590 \mathrm{ind} \cdot \mathrm{m}^{-3}\right)\left(\frac{1 \mathrm{~m}^{3}}{10^{6} \mathrm{ml}}\right) \\
\therefore \mathcal{U}_{c}=0.0323 \mathrm{~h}^{-1}
\end{gathered}
$$

From Experiment 2 with dominant diatom Pseudonitzschia of Table 1 in Manuscript 3 [43], the grazing loss rate by krill of Euphausia superba from 5.7 [BSi] to 1.7 [BSi] with duration of grazing phase $(96 \mathrm{~h})$ and Calanus propinquus from 6.5 [BSi] to 1.9 [BSi] with duration of grazing phase $(90 \mathrm{~h})$ were, respectively, calculated with the assumption of the first order decay [45] as below:

$$
\frac{C}{C_{0}}=\mathrm{e}^{-\mathcal{U}_{k} t}
$$

where $C=$ free concentration of Biogenic Silica $\left[\mathrm{BS}_{\mathrm{i}}\right]\left(\mu \mathrm{mol} \cdot \mathrm{l}^{-1}\right)$.

$C_{0}=$ initial concentration of Biogenic Silica $\left[\mathrm{BS}_{\mathrm{i}}\right]\left(\mu \mathrm{mol} \cdot \mathrm{l}^{-1}\right)$.

$$
\begin{gathered}
\frac{1.7}{5.7}=\mathrm{e}^{-\mathcal{U}_{k_{1}}(96)} \\
\therefore \mathcal{U}_{k_{1}}=0.0126 \mathrm{~h}^{-1}
\end{gathered}
$$

for Euphausia superba,

$$
\begin{aligned}
\frac{1.9}{6.5} & =\mathrm{e}^{-\mathcal{U}_{k_{2}}(90)} \\
\therefore \mathcal{U}_{k_{2}} & =0.0137 \mathrm{~h}^{-1}
\end{aligned}
$$

for Calanus propinquus.

Since diatoms were mainly (70\%) ingested by Euphausia superba and Calanus propinquus, as shown in "BSi ingested \%" of Table 1 in Manuscript 3 [43], the grazing rate by krill, $\mathcal{U}_{k}$, was given by,

$$
\therefore \mathcal{U}_{k}=\mathcal{U}_{k_{1}}+\mathcal{U}_{k_{2}}=0.0263 \mathrm{~h}^{-1}
$$

Since $\mathcal{U}_{c}$ and $\mathcal{U}_{k}$ were determined, the apparent diatoms growth rate was given by,

$$
\mu_{d}=\mathcal{U}_{c}+\mathcal{U}_{k}=0.0323 \mathrm{~h}^{-1}+0.0263 \mathrm{~h}^{-1}=0.0586 \mathrm{~h}^{-1}
$$

From Figure 2 in Manuscript 1 [43], “diatoms \% contribution to abundance in control bottles" were given as a function of days with 5 interpolated data points such that time "(days)" and, "diatoms \% contribution to abundance after the first iron fertilization $\left(X_{d}\right)$ " were, $\left(t, X_{d}\right)$ as $(2,55),(7,65),(8,62),(11,75)$ and $(16,80)$, respectively. All the diatom \% contributions $\left(X_{d}\right)$ were divided by the initial diatom \% contribution of $56\left(X_{d o}\right)$ to get $\left(X_{d} / X_{d o}\right)$ and $\ln \left(X_{d} / X_{d o}\right)$ A good linear relationship $\left(\mathrm{R}^{2}=0.8855\right)$ between $\ln \left(X_{d} / X_{d o}\right)$ and time (days) was shown in Figure 11 with slope of $0.0893 \mathrm{~d}^{-1}$ or $0.0037 \mathrm{~h}^{-1}$, as the apparent growth rate of diatoms after grazed by copepods and krill, $\mu_{d}$. 


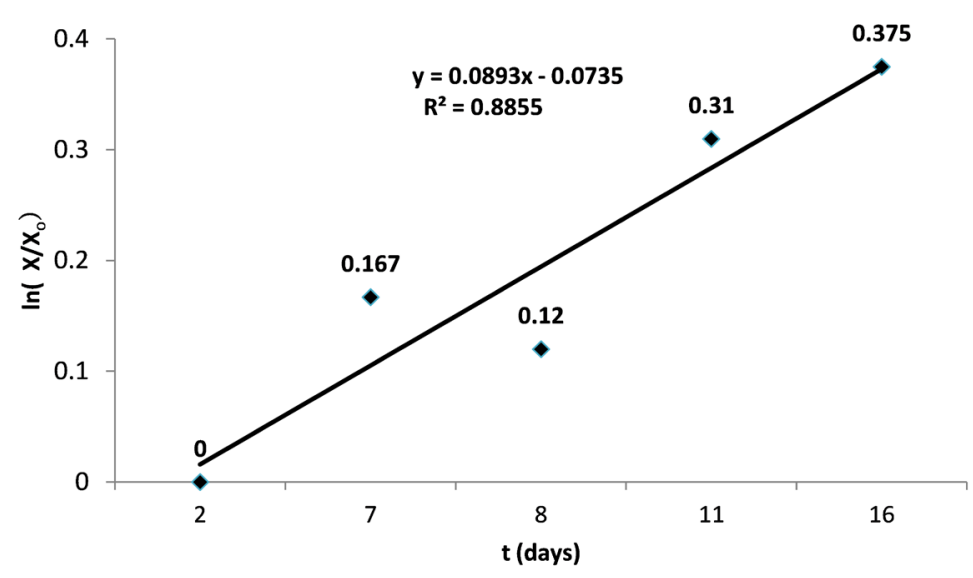

Figure 11. Logarithmic ratio of frequency distribution of the major prey taxa in the control bottles over the course of the experimental days to determine the apparent diatoms growth rate after grazed by copepods and krill, whose data were interpolated and rearranged from Figure 2 in Manuscript 1 [43] for the present study.

It was summarized as;

1) The apparent growth rate of diatoms $\left(0.0037 \mathrm{~h}^{-1}\right)$ and the sum $\left(0.0586 \mathrm{~h}^{-1}\right)$ of grazing loss rates by copepods $\left(0.0323 \mathrm{~h}^{-1}\right)(52 \%)$ and krill $\left(0.0263 \mathrm{~h}^{-1}\right)(42 \%)$ gave the overall diatoms growth rate of $0.0623 \mathrm{~h}^{-1}(=0.0037+0.0586)$ equivalent to $1.5 \mathrm{~d}^{-1}$, which was comparable to $1.79 \mathrm{~d}^{-1}$ between day 4 and 7 of the centric diatom of Chaetocerus debilis in the western Subarctic Pacific [46],

2) The doubling rate of diatoms after grazed by copepods and krill was 0.13 $\mathrm{d}^{-1}$ from dividing $\left(0.0037 \mathrm{~h}^{-1}\right)(24 \mathrm{~h} / \mathrm{d})$ by $\ln 2$, which was comparable to 0.18 $0.67 \mathrm{~d}^{-1}$ of chlorophyll in the Antarctic [6],

3) For the efficient sequestration of atmospheric $\mathrm{CO}_{2}$, it was necessary to increase the amount of diatom due to the relatively small apparent growth rate of residual diatom $\left(0.0037 \mathrm{~h}^{-1}, 6 \%\right)$. To overcome such extreme grazing controls (94\%) by copepods and krill, the duration and area of the iron enrichment experiment should be extended to more than 3 months (Dec.-Feb.) when chlorophyll-a reached its peak concentration $\left(\geq 0.75 \mathrm{mg} \cdot \mathrm{m}^{-3}\right)$ with a large area of phytoplankton blooms $\left(\sim 145,000 \mathrm{~km}^{2}\right)$, as observed in the South Georgia [47] of the Southern Ocean with fast ACC for the high mass flow rate of diatoms stimulated by the Fe-replete buoyant carrier.

\section{Conclusion}

The present study examined empirically the Fe limitations induced by sulfur compounds of volcanic ash and hydrogen sulfide to improve the iron fertilization for the efficient phytoplankton productivity and estimated analytically the grazing control by copepods and krill over diatoms in HNLC regions. The limitation of Fe for phytoplankton growth in HNLC regions was confirmed by sulfur compounds such as volcanic ash and hydrogen sulfide $\left(\mathrm{H}_{2} \mathrm{~S}\right)$ in batch cultures. Distribution of XRD pattern for the sedimentary materials induced by the chemical reaction between dissolved $\mathrm{FeSO}_{4} \cdot 7 \mathrm{H}_{2} \mathrm{O}$ and $\mathrm{H}_{2} \mathrm{~S}$ gas bubbling in dis- 
tilled water, showed that the chemical sediment of $\mathrm{Fe}_{3} \mathrm{~S}_{4}$ constituted $4.06 \mathrm{wt} \%$ of total sedimentary materials among sulfur, iron oxide and $\mathrm{Fe}_{3} \mathrm{~S}_{4}$. The low productivity of $6 \%$ diatoms was caused by grazing control in HNLC regions with $52 \%$ by copepods and $42 \%$ by krill on the basis of data analysis in 2000 EisenEx Experiment. Oceans were classified by four characteristic regions (HNLC, LNLC, HNHC and LNHC) based on the relative magnitude of the accumulation rates of Fe from deserts and S compounds from volcanoes. All of the previous iron fertilization experiments were conducted at volcanic sulfur compounds enriched HNLC regions. The present study revealed that the enhanced phytoplankton productivity in batch culture without sedimentary iron sulfides can be possible only if sulfur compounds are minimal, as is in Shag Rocks $\left(53^{\circ} \mathrm{S}, 42^{\circ} \mathrm{W}\right)$ of South Georgia in Scotia Sea in the Southern Ocean.

\section{Acknowledgements}

The authors express sincere gratitude to Hiroyuki Yokoi, ICST, Tokyo, Japan, Kristi L. Wallace of Alaska Volcano Observatory, United States Geological Survey, H. C. Ryu of COSMAX, Prof. J. Y. Hwang of the Department of Earth and Environmental Sciences of Pusan National University, and Dr. H. C. Choi, South Korea, for providing samples of Ontake volcanic ash, Kasatochi volcanic ash, Lombok volcanic ash, Pinatubo volcanic ash, Baekdu volcanic stone and Tongyoung clay, St. Helens volcanic ash, respectively. Data from the Ph.D. thesis in 2000 EisenEx Experiment were kindly permitted by Lecturer Dr. Sabine Schultes of Department of Biology at II Ludwig-Maximilians-University of Munich, Germany for the present study. This work was funded by companies of ICST and G-LAND, and the University of Suwon.

\section{Conflicts of Interest}

The authors declare no conflicts of interest regarding the publication of this paper.

\section{References}

[1] Dugdale, R.C. and Wilkerson, F.P. (1991) Low Specific Nitrate Uptake Rate: A Common Feature of High-Nutrient, Low-Chlorophyll Marine Ecosystems. Limnology and Oceanography, 36, 1678-1688. https://doi.org/10.4319/1o.1991.36.8.1678

[2] Martin, J.H. and Fitzwater, S.E. (1988) Iron Deficiency Limits Phytoplankton Growth in the North-East Pacific Subarctic. Nature, 331, 341-343. https://doi.org/10.1038/331341a0

[3] Maher, B.A., Prospero, J.M., Mackie, D., Gaiero, D., Hesse, P.P. and Balkanski, Y. (2010) Global Connections between Aeolian Dust, Climate and Ocean Biogeochemistry at the Present Day and at the Last Glacial Maximum. Earth-Science Reviews, 99, 61-97. https://doi.org/10.1016/j.earscirev.2009.12.001

[4] Langmann, B. (2014) On the Role of Climate Forcing by Volcanic Sulphate and Volcanic Ash. Advancesin Meteorology, 2014, Article ID 340123. https://doi.org/10.1155/2014/340123

[5] Mcanena, A. (2011) The Reactivity and Isotopic Fractionation of Fe-Bearing Miner- 
als during Sulfidation: An Experimental Approach. Ph.D. Thesis, Newcastle University.

[6] Martin, J.H., Gordon, M. and Fitzwater, S.E. (1991) Iron Limitation? Limnology and Oceanography, 36, 1793-1802. https://doi.org/10.4319/lo.1991.36.8.1793

[7] Martin, J.H. and Chisholm, P. (1992) Design for a Mesoscale Iron Enrichment Experiment. U.S. JGOFS Planning Report 15, Woods Hole Oceanographic Institution.

[8] McKey, R.M., Law, C.S., Hutchins, D.A. and Abraham, E.R. (2005) FeCycle: Attempting an Iron Biogeochemical Budget from a Mesoscale $\mathrm{SF}_{6}$ Tracer Experiment in Unperturbed Low Iron Waters. Global Biogeochemical Cycle, 19, GB4S20.

[9] Naqvi, S.W.A., Moffett, W., Gauns, M.U., Narvekar, P.V., Pratihary, A.K., Naik, H., Shenoy, D.M. and Jayakumar, D.A. (2010) The Arabian Sea as a High-Nutrient, Low-Chlorophyll Region during the Late Southwest Monsoon. Biogeosciences, 7, 2091-2100. https://doi.org/10.5194/bg-7-2091-2010

[10] Lin, I.-I., Hu, C., Li, Y.H., Ho, T.Y., Fischer, T.P. Wong, G.T.F., Wu, J., Huang, C.W., Chu, D.A., Ko, D.S. and Chen, J.P. (2011) Fertilization Potential of Volcanic Dust in the Low-Nutrient Low-Chlorophyll Western North Pacific Subtropical Gyre: Satellite Evidence and Laboratory Study. Global Biogeochemical Cycles, 25, GB1006. https://doi.org/10.1029/2009GB003758

[11] Tan, S.C., Yao, X., Gao, H.W., Shi, G.Y. and Yue, X. (2013) Variability in the Correlation between Asian Dust Storms and Chlorophyll-a Concentration from the North to Equatorial Pacific. PLoS ONE, 8, e57656. https://doi.org/10.1371/journal.pone.0057656

[12] Sachoemar, S.I. and Yanagi, T. (2001) Seasonal Variation of Water Characteristics in the Northern Coastal Area of Java. Lamer, 39, 77-85.

[13] Duggen, S., Olgun, N., Croot, P., Hoffmann, L., Dietze, H., Delmell, P. and Teschner, C. (2010) The Role of Airborne Volcanic Ash for the Surface Ocean Biogeochemical Iron-Cycle: A Review. Biogeosciences, 7, 827-844.

https://doi.org/10.5194/bg-7-827-2010

[14] Atkins, P. and Paula, J.D. (2010) Physical Chemistry. 9th Edition, Oxford University Press, New York.

[15] Fanning, D.S., Rabenhorst, M.C., James, B.R., Wagner, D.P. and Lowery, D.C. (2012) Rethinking Sulfidization and the Role of Hydrogen Sulfide. 7 th International Acid Sulfate Conference Proceedings, Finland, 44-46.

[16] Aquilina, A., Homoky, W., Hawkes, J.A. and Lyons, T.W. (2014) Hydrothermal Sediments Are a Source of Water Column Fe and Mn in the Bransfield Strait, Antarctica. Geochimica et Cosmochimica Acta, 137, 64-80. https://doi.org/10.1016/j.gca.2014.04.003

[17] Korehi, H., Blöthe M., Sitnikova, M.A., Dold, B. and Schippers, A. (2013) Metal Mobilization by Iron- and Sulfur-Oxidizing Bacteria in a Multiple Extreme Mine Tailings in the Atacama Desert, Chile. Environmental Science \& Technology, 47, 2189-2196.

[18] Fornari, D., Tivey, M., Schouten, H., Perfit, M., Yoerger, D., Bradley, A., Edwards, M., Haymon, R., Scheirer, D., Damm, K.V., Shank, T. and Soule, A. (2004) Submarine Lava Flow Emplacement at the East Pacific Rise $9^{\circ} 50^{\prime} \mathrm{N}$ : Implications for Uppermost Ocean Crust Stratigraphy and Hydrothermal Fluid Circulation. Geophysical Monograph, 148, 187-218. https://doi.org/10.1029/148GM08

[19] https://www.avo.alaska.edu/volcanoes/

[20] Beget, J.E. (1994) A 500-Year-Long Record of Tephra Falls from Redoubt Volcano 
and Other Volcanoes in Upper Cook Inlet, Alaska. Journal of Volcanology and Geothermal Research, 62, 55-67. https://doi.org/10.1016/0377-0273(94)90028-0

[21] http://erebus.nmt.edu/

[22] http://oceancolor.gsfc.nasa.gov

[23] http://healthdocbox.com/Nutrition/72481908-Total-organic-carbon-at-bats-remem ber-that-doc-98-of-the-toc.html

[24] https://earthobservatory.nasa.gov/images/6006/sierra-negra-sulfur-dioxide-emissio ns

[25] Scholz, F., McManus, J., Mix, A.C., Hensen, C. and Schneider, R.R. (2014) The Impact of Ocean Deoxygenation on Iron Release from Continental Margin Sediments. Nature Geoscience, 7, 433-437. https://doi.org/10.1038/ngeo2162

[26] http://pubs.usgs.gov/gip/dynamic/slabs.html

[27] Ebersbach, F., Assmy, P., Martin, P., Schulz, I., Wolzenburg, S. and Nothig, E.M. (2014) Particle Flux Characterization and Sedimentation Patterns of Protistan Plankton during the Iron Fertilization Experiment LOHAFEX in the Southern Ocean. Deep Sea Research Part I, 89, 94-103. https://doi.org/10.1016/j.dsr.2014.04.007

[28] Dixon, D., Mayewski, P.A., Kaspari, S., Kreutz, K.J. and Hamilton, G.S. (2005) A 200 Year Sulfate Record from 16 Antarctic Ice Cores and Associations with Southern Ocean Sea-Ice Exten. Annals of Glaciology, 41, 155-166. https://doi.org/10.3189/172756405781813366

[29] United States Geological Survey (2011) Volcano Hazards Program. 22.

[30] Trick, C.G., Bill, B.D., Cochlan, W.P., Wells, M.L. Trainer, V.L. and Pickell, L.D. (2010) Iron Enrichment Stimulates Toxic Diatom Production in High-Nitrate, Low-Chlorophyll Areas. Proceedings of the National Academy of Sciences of the United States, 107, 5887-5892. https://doi.org/10.1073/pnas.0910579107

[31] Venables, H. and Moore, C.M. (2010) Phytoplankton and Light Limitation in the Southern Ocean: Learning from High-Nutrient, High-Chlorophyll Areas. Journal of Geophysical Research, 115, C02015. https://doi.org/10.1029/2009JC005361

[32] Barker, P.F. (2001) Scotia Sea Regional Tectonic Evolution: Implications for Mantle Flow and Palaeocirculation. Earth-Science Review, 55, 1-39. https://doi.org/10.1016/S0012-8252(01)00055-1

[33] Gaiero, D.M., Probast, J.L., Depetris, P.J., Bidart, S.M. and Leletyer, L. (2003) Iron and Other Transition Metals in Patagonian Riverbone and Windborne Materials: Geochemical Control and Transport to the Southern South Atlantic Ocean. Geochimica et Cosmochimica Acta, 67, 3603-3623. https://doi.org/10.1016/S0016-7037(03)00211-4

[34] Borrione, I., Aumont, O., Nielsdottir, M.C. and Schlitzer, R. (2014) Sedimentary and Atmospheric Sources of Iron around South Georgia, Southern Ocean: A Modeling Perspective. Biogeosciences, 11, 1981-2001. https://doi.org/10.5194/bg-11-1981-2014

[35] Meredith, M.P., Watkins, J.L., Murphy, E.J., Ward, P., Bone, D.G., Thorpe, S.E., Grant, S.A. and Ladkin, R.S. (2003) Southern ACC Front to the Northeast of South Georgia: Pathways, Characteristics, and Fluxes. Journal of Geophysical Research, 108, 3162. https://doi.org/10.1029/2001JC001227

[36] Morris, P.J. and Charette, M.A. (2013) A Synthesis of Upper Ocean Carbon and Dissolved Iron Budgets for Southern Ocean Natural Iron Fertilisation Studies. Deep-Sea Research II, 90, 147-157. 
[37] Lommer, M., Specht, M., Roy, A.S., Kraemer, L., Andreson, R., Gutowska, M.A., Wolf, J., Bergner, S.V., Schilhabel, M.B., Klostermeier, U.C., Beiko, R.G., Rosenstiel, P., Hippler, M. and LaRoche, J. (2012) Genome and Low-Iron Response of an Oceanic Diatom Adapted to Chronic Iron Limitation. Genome Biology, 13, R66. https://doi.org/10.1186/gb-2012-13-7-r66

[38] Walsh, J.J. and Steidinger, K.A. (2001) Saharan Dust and Florida Red Tides: The Cyanophyte Connection. Journal of Geophysical Research, 106, 11,597-11,612. https://doi.org/10.1029/1999JC000123

[39] Bienfang, P.K. and Harrison, P.J. (1984) Sinking Rate Response of Natural Assemblages of Temperateand Subtropical Phytoplankton to Nutrient Depletion. Marine Biology, 83, 293. https://doi.org/10.1007/BF00397462

[40] Yool, A. and Tyrrell, T. (2003) Role of Diatoms in Regulating the Ocean's Silicon Cycle. Global Biogeochemical Cycles, 17, 1103. https://doi.org/10.1029/2002GB002018

[41] Sverdrup, H. (1953) On Conditions for the Vernal Blooming of Phytoplankton. ICES Journal of Marine Science, 18, 287-295.

https://doi.org/10.1093/icesjms/18.3.287

[42] Atkinson, A., Ward, P., Hill, A., Brierley, A.S. and Cripps, G.C. (1999) Krill-Copepod Interactions at South Georgia, Antarctica, II. Euphausia superba as a Major Control on Copepod Abundance. Marine Ecology Progress Series, 176, 63-79.

[43] Schultes, S. (2004) The Role of Mesozooplankton Grazing in the Biogeochemical Cycle of Silicon in the Southern Ocean. PhD Thesis, Universität Bremen, Bremen, Germany.

[44] Atkinson, A. (1996) Subantarctic Copepods in an Oceanic, Low Chlorophyll Environment: Ciliate Predation, Food Selectivity and Impact on Prey Populations. Marine Ecology Progress Series, 130, 85-96. https://doi.org/10.3354/meps130085

[45] Aiba, S., Humphrey, A.E. and Millis, N.F. (1973) Biochemical Engineering. Academic Press, New York.

[46] Tsuda, A., Takeda, S., Saito, H., Nishioka, J., Nojiri, Y., Kudo, I., Kiyosawa, H., Shiomoto, A., Imai, K., Ono, T., Shimamoto, A., Tsumune, D., Yoshimura, T., Aono, T., Hinuma, A., Kinugasa, M., Suzuki, K., Sohrin, Y., Noiri, Y., Tani, H., Deguchi, Y., Tsurushima, N., Ogawa, H., Fukami, K., Kuma, K. and Saino, T.A. (2013) Mesoscale Iron Enrichment in the Western Subarctic Diatom Bloom. Science, 300, 958-961. https://doi.org/10.1126/science. 1082000

[47] Borrione, I. and Schlitzer, R. (2013) Distribution and Recurrence of Phytoplankton Blooms around South Georgia, Southern Ocean. Biogeosciences, 10, 217-231.

https://doi.org/10.5194/bg-10-217-2013 